\title{
Biological monitoring of wild thicklip grey mullet (Chelon labrosus), golden grey mullet (Liza aurata), thinlip mullet (Liza ramada) and flathead mullet (Mugil cephalus) (Pisces: Mugilidae) from different Adriatic sites: meristic counts and skeletal anomalies
}

\author{
C. Boglione*, C. Costa, M. Giganti, M. Cecchetti, P. Di Dato, \\ M. Scardi, S. Cataudella \\ Biology Department, University of Rome 'Tor Vergata', Via della Ricerca Scientifica, 00133 Rome, Italy
}

Received 8 January 2004; accepted 29 August 2005

\begin{abstract}
This paper reports on a part of PRISMA project, funded by the Italian Ministry of Education, University and Research (M.U.R.S.T.), involving the biomonitoring of fish populations in two different Adriatic Sea sites by using some integrated descriptors at organismic level (skeletal anomalies and meristic count variation). Given the scarcity of up-to-date data on biology, physical and chemical oceanography, and environmental geophysics, as well on the degree of pollution of this Sea, the goal of the project was to contribute at enhancing the knowledge on environmental biology of Adriatic Sea. In particular, this part of the project analyzed different samplings of some mullets species for the presence of skeletal malformations under the hypothesis that stressed environment should induce alteration in skeletal development pattern in fish, as indicated by many authors. So, the investigation on mullets skeletal structures was utilized to monitor two different Adriatic Sea sites, where exhaustive information (chemical analysis of water and sediment, i.e.) on environmental conditions lack.

We observed a total of 2169 individuals, $79 \%$ of which were fry and the remainder sub-adults, collected during the seasonal migration in freshwater (spring and autumn 1997) by purse-seine. Chelon labrosus accounted for $18 \%$ of the samples, Liza aurata $24 \%$, Liza ramada $22 \%$ and Mugil cephalus 36\%. Fish were sampled in two Adriatic sites, Sacca di Goro (northern Italy, Po River delta) and Lake Lesina (southern Italy). Other samplings from Tyrrhenian Sea (Fiumicino, Tiber river mouth) and from an aquaculture facility (Grosseto) were used in order to obtain additional information on skeletal plasticity of Mugilidae. Observations included meristic counts and skeletal anomalies and some multi-parametric analyses were performed on the data set. The results showed significant differences among the type and rate of skeletal anomalies observed in the fish samples: as far as Adriatic samples are concerned, higher malformation charge was observed in the Sacca di Goro individuals than in Lesina ones. Further, $L$. aurata showed a non-specific skeletal pattern and the lowest frequency of deformed individual (8.6\% of total
\end{abstract}

\footnotetext{
* Corresponding author. Fax: +390672595965.

E-mail address: boglione@uniroma2.it (C. Boglione).
} 
observed individuals), unlike C. labrosus, L. ramada and L. aurata. So, these Mugilidae species resulted to be differently affected by skeletal anomalies according to the sampling site.

(C) 2005 Elsevier Ltd. All rights reserved.

Keywords: Chelon labrosus; Liza aurata; Liza ramada; Meristic characters; Mugil cephalus; Skeletal anomalies; Skeletal descriptors

\section{Introduction}

The Italian Ministry of Education, University and Research (M.U.R.S.T.) has funded an Adriatic Sea Research and Experimentation Program (PRISMA) aimed at enhancing knowledge of its biology, physical and chemical oceanography, and environmental geophysics. This paper reports the results obtained in a part of phase two PRISMA, involving the biomonitoring of fish populations in two different Adriatic Sea sites using some integrated descriptors at organismic level (skeletal anomalies and meristic count variation).

The monitored fish species are members of the Mugilidae family, order Perciformes (thick lipped mullet, Chelon labrosus; golden grey mullet, Liza aurata; thinlip mullet, Liza ramada; flathead mullet, Mugil cephalus), which are cosmopolitan fish inhabiting all tropical and temperate seas. They are found inshore, and enter lagoons, estuaries and some species also in rivers. Utilized as a food fish in many tropical and subtropical regions, they play an important role in world fishery and aquaculture. Mullet are characterized by a wide range of feeding adaptations to the estuarine environment, according to trophic availability: each species in the same environment is able to utilize the food distributed from the thin water surface film to bottom mud, either by direct grazing or using plant-detritus food chains as an energy source. At the same time, each species has evolved particular mouth and pharyngeal structures so as to preferentially use different substrates and granulometries (Capanna et al., 1974; Mariani et al., 1987; Crosetti and Cataudella, 1995). Thick lipped mullet adults feed on algae, organic debris and sediment, and the tubercles on the upper lip enable them to scrape the hard substrate, which is rich in encrusted organisms; the genus Liza, in particular L. ramada, shows considerable adaptation to small particles, such as soft mud, and M. cephalus prefers sandy substrates and larger particles (Capanna et al., 1974; Mariani et al., 1987).
Each mullet species spawns in different periods of the year, reproduction takes place at sea, and eggs and larvae are pelagic. The spawning sequence of mullet species is followed by fry (young-of-the-year) recruitment in monospecific schools to protected areas along the coasts or in estuaries (Yashuov and Berner-Samsonov, 1970). Fry enter brackish water and adults return to the sea for reproduction. Fry are approximately 2 months of age when they are first found near the coasts (Crosetti and Cataudella, 1995) and the timing of their seasonal occurrences in coastal areas is the first identification key used to recognize the different species collected. Unlike adults, all the Mugilidae larvae and post-larvae feed mostly on zooplankton; during the recruitment phase both larval (planktivorous) and adult (grazing/detrivitorous) feeding strategies coexist in relative proportions, changing according to the food type available. In the Mediterranean sea, there has been a decline in fry availability of some mullet species in recent years due to pollution and overfishing of parent stocks: $M$. cephalus, for instance, has shown a decrease in number, whereas L. ramada, which is more tolerant to coastal organic pollution and eutrophication, is still abundant despite massive fishing (Crosetti and Cataudella, 1995).

This paper reports the inspection of young-of-theyear and sub-adult stages of the above-mentioned mullet species for morphological anomalies (including skeletal deformities and variation in meristic counts) sampled in two different Adriatic sites. Morphological anomalies are common in reared fish but rare in natural populations from undisturbed ecosystems (Dahlberg, 1970; Daoulas et al., 1991; Da Cunha and Antunes, 1999) and many authors have hypothesized a relationship between skeletal anomalies and environmental conditions (Dahlberg, 1970; Bengtsson, 1979, 1988; Karr, 1981; Sloof, 1982; Bengtsson et al., 1985, 1988; Hardig et al., 1988; Mayer et al., 1988; O'Connor and Huggett, 1988; Westeinhagen et al., 1988; Haya, 1989; Weigand et al., 
1989; Weis and Weis, 1989; Carls and Rice, 1990; Fausch et al., 1990; Lindsejöö and Thulin, 1992; Oberdoff and Hughes, 1992; Whittle et al., 1992; Von Westernhagen and Dethlefsen, 1997; Kirchhoff et al., 1999). Consequently, skeletal anomalies have been recently used as indicators or biomarkers of pollution stress in fish (Savvaitova et al., 1995; Svanberg, 1996; Svanberg and Bengtsson, 1996; Wilson and Tillitt, 1996; Ewald, 1999; Karen et al., 2001; Latif et al., 2001; Pastva et al., 2001; Klumpp et al., 2002; Haga et al., 2003) as terata are considered as permanent biomarkers of toxicity, i.e. they are utilized to reliably identify and evaluate the impact of selenium on fish populations (Lemly, 1997, 2002) or in environmental impact studies by the Swedish Environmental Protection Board on kraft mill bleach effluent effects on wild fish (Bengtsson, 1988).

Meristic count variations may also be included among the skeletal anomalies, since those elements of taxonomic identification are under the control of the genotype but are also modulated by environmental conditions. During ontogenesis, the expression of a genetically predetermined phenotype is modulated by developmental homeostasis, which acts against environmental and genetic disturbances through canalisation and developmental stability. The first component acts by reducing the phenotypic variation associated with a particular trait (Clarke, 1995). Developmental stability is the capacity of a genotype to constantly and precisely express the same phenotype when exposed to the same environmental conditions during development (Alford et al., 1997). So, when extensive environmental and/or genetic stress prevails over developmental homeostasis, then fluctuating asymmetry, variations in meristic counts and/or skeletal anomalies may arise.

This study utilized the investigation on mullets skeletal anomalies to monitor two different Adriatic Sea sites, whose detailed information on environmental conditions are lacking, with the underlain hypothesis that more 'stressed' environment should induce higher frequency of skeletal anomalies. The fact is that this study does not try to investigate the possible causes of the observed abnormalities, but it is aimed to use skeletal descriptors for a first screening of environment condition. On the other hand, it is well documented in literature (see Divanach et al., 1996 for a review), as well as observed in our experience, that different causes may provoke the same anomaly or the same cause can induce different anomalies, according to the species, the exposition time, the developmental stage. The problem is not what anomaly to find for knowing what substance perturbates the environment, but to find or not significative presence of anomalies as indication of perturbated environment.

As fry entering brackish water for the first time have spent all their previous life in the sea, most likely not far from the point of entry, differently from subadults that presumably passed some period also in brackish or fresh water, we sampled both life stages in order to check differences in skeletal anomalies as a function of life history. Further, to exclude the possibility that the skeletal anomalies were due to some species-specific skeletal plasticity, we performed the same type of observation also on individuals of different origin, at least in some of the inspected species (e.g. from the central Tyrrhenian Sea and from artificial reproduction carried out in an aquaculture facility).

\section{Materials and methods}

\subsection{Area description}

Some $40 \%$ of the total fish were caught at Sacca di Goro $\left(44^{\circ} 47^{\prime}-44^{\circ} 50^{\prime} \mathrm{N}\right.$ and $12^{\circ} 15^{\prime}-12^{\circ} 20^{\prime} \mathrm{E}$, Ferrara, Italy, Fig. 1), the southernmost shallow-water embay-

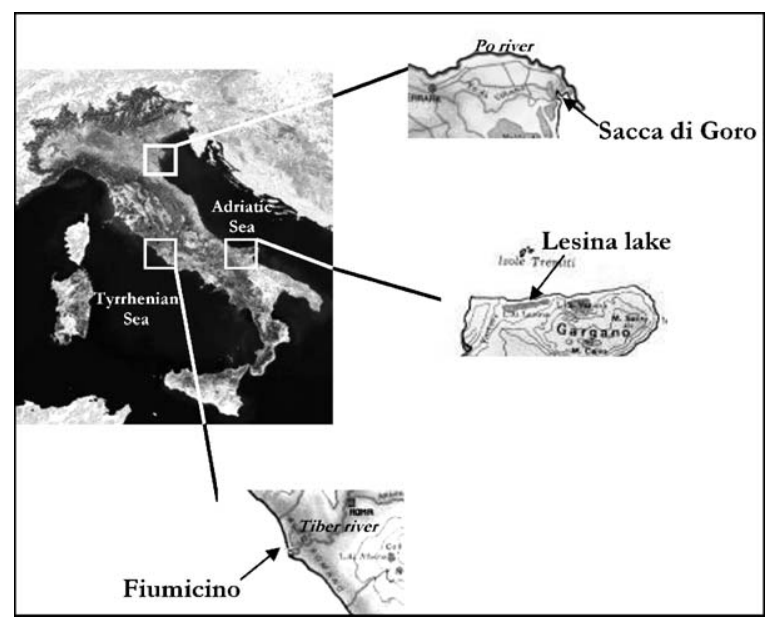

Fig. 1. Sampling sites. 
ment of the Po River Delta, located on the northern Adriatic Coast of Italy. The surface area is 260 ha, the mean depth $1.5 \mathrm{~m}$ and the tidal range is no greater than $100 \mathrm{~cm}$. The water temperature ranges between $5{ }^{\circ} \mathrm{C}$ in January and $30{ }^{\circ} \mathrm{C}$ in July (Giordani et al., 1997). The salinity (psu) in the lagoon and in the sea just outside it was 23.8 and 32.0 in the spring of 1997 and 24.2 and 30.0 in the autumn, respectively. It is a highly eutrophic coastal lagoon, intensely impacted by human use, with access to the northern Adriatic Sea restricted by sand bars. Freshwater comes from the Po River tributary, the Po di Goro, with a residence time varying from days to weeks, depending largely on the flow of the Po di Goro (Christian et al., 1996). The Po River is the largest Italian river $(652 \mathrm{~km})$, with a mean discharge rate into the Adriatic Sea of $1600 \mathrm{~m}^{3} \mathrm{~s}^{-1}$ (Raicich, 1994), and it accounts for $49 \%$ of the total riverine inputs to the Adriatic Sea (Tankéré et al., 2000). It drains the most industrialized Italian regions and the civil discharges of almost 19 millions of inhabitants, and influences the particle, nutrient and pollutant budgets of the entire Adriatic Sea (Matteucci and Frascari, 1997; Fabbri et al., 2001). The Po River transports, for example, about $65 \mathrm{t}-\mathrm{Hg} /$ year (Orio, 1984). Relatively high levels of mercury were measured in suspended matter collected in the lower Po River (12-260 ng L ${ }^{-1}$, Fabbri et al., 2001) and off-shore from the Po mouth (4.7-9.7 $\mathrm{ng} \mathrm{L}^{-1}$, Ferrara and Maserti, 1992) and a total mercury sedimentation rate of approximately $0.75 \mathrm{mg} \mathrm{m}^{-2}$ year $^{-1}$ in an area affected by the Po River plume is estimated by Coquery et al. (1996). Furthermore, elevated concentrations of trace metals (copper, $7.14 \mathrm{nM}$ and nickel, $9.06 \mathrm{nM}$ ) in the Adriatic Sea are only to be found close to boundary inputs, in particular the Po River, where a concomitant increase in concentration of zinc $(3.69 \mathrm{nM})$ and cadmium $(0.083 \mathrm{nM})$ was found close to the sediment-water interface and negatively correlated with salinity (Tankéré and Statham, 1996). Bibliographic data on the Goro lagoon refer that is generically affected by both chronical (nutrient pollution, contamination by heavy metals, clam cultivation, siltation and introduced species) and acute (algal blooms) disturbances and it is considered as a study-case of highly impacted coastal environments (Marchini et al., 2004). Furthermore, the oxygen depletion and low redox potential, consequences of the frequent dystrophic crises occurring in late spring and during summer, due to decomposition of huge amounts of macroalgae, may accelerate the mobilization of radioactive elements accumulated in the sediment and made them available in the water column (Delaune et al., 1978; Robbins and Edgington, 1975; Bondavalli, 2003).

It was impossible to sample $C$. labrosus sub-adults at Goro because the sub-adults and adults of this species rarely enter this lagoon, and fishermen do not fish this species, for which there is little demand on the local market, and the occasional catches are made using "flying nets", which are illegal in Italy.

Some $42 \%$ of the fish were caught in Lake Lesina $\left(41^{\circ} 88^{\prime} \mathrm{N}-15^{\circ} 35^{\prime} \mathrm{E}\right.$, Foggia, Apulia, Italy, Fig. 1), a coastal eutrophic lagoon with a surface of 5100 ha and a mean depth of $0.8 \mathrm{~m}$. It has an elongated and narrow shape, running in an east-west direction, and it is connected with the Adriatic Sea by natural and artificial canals interspersed with sand dunes. Freshwater inputs are represented mainly by the perennial rivers Lauro and Zanella in the south eastern area of the lagoon; there are also two pumping stations that discharge agricultural drainage water in the south of the lake, where the land is lower than the average sea level. Consequently, salinity varies greatly between the western (25.8-38.5 psu) and the eastern (6.5$15.5 \mathrm{psu})$ parts. Lesina is exposed to strong seasonal variations of temperature (which ranges from $7{ }^{\circ} \mathrm{C}$ in winter to $26^{\circ} \mathrm{C}$ in summer) and salinity (between 11 and $34 \mathrm{psu}$ ). In 1992, the Environment Ministry included the Lesina Lagoon in the Gargano National Park. No other data are available in literature on the pollution degree of this site that can be considered a eutrophic lagoon, with diffuse sources (agriculture, surface runoff) of pollution.

The remaining $17.8 \%$ of the sampled fish were used in order to obtain additional information on skeletal plasticity of Mugilidae: $15.6 \%$ was accounted for by M. cephalus sampled at Fiumicino (Rome, Italy, Fig. 1) while $2.2 \%$ were C. labrosus obtained by induced reproduction and rearing in an aquaculture facility (Grosseto, Italy).

Fiumicino is located at the Tiber river estuary $\left(41^{\circ} 46^{\prime} \mathrm{N}-12^{\circ} 13^{\prime} \mathrm{E}\right.$, central Tyrrhenian Sea) and mullet at the fry stage were caught by purse seine in the shallow seawaters adjacent to the artificial northern 
Tiber channel, during their first approach to the coast (July 1996). The Tiber river is the third largest Italian hydrographic basin; it is $405 \mathrm{~km}$ long and covers an area of over $17,000 \mathrm{~km}^{2}$. As many as 4.5 millions of inhabitants are resident in the Tiber river watershed, whose $60 \%$ are concentrated in Rome (ENVIBASEProject, 1988). Pollution is mainly due to agriculture and municipal effluents rather than to industrial activities and the global quality is badly affected in the last $50 \mathrm{~km}$ by the untreated sewage of about half a million people flows directly into the Tiber, and the confluence of the heavily polluted tributary Aniene river. Furthermore, Minissi and Lombi (1997) evidencied levels of heavy metal contamination in the sediments collected in the urban area higher than the background value found in sediment samples collected in unpolluted areas, but the generally alkaline or subalkaline $\mathrm{pH}$ value of the Tiber water should maintain these elements as less bioavailable. Data on Tiber river mutagenicity obtained in three different campaigns demonstrated a recovery of the mutagenic contamination in the last campaign (1995) with respect to the values observed in the first two campaigns (1898 and 1992, respectively) (Minissi and Lombi, 1997). Substantially, Tiber pollution is mainly due to urban population discharging with high levels of faecal waste and ammoniacal nitrogen.

One batch of fish ( $n=246)$ was fixed $(73 \%$ of this sample, Table 1) immediately after catching. The others were transferred to the Laboratory of Experimental Ecology and Aquaculture of the University of Rome 'Tor Vergata', maintained in outdoor circular tanks $\left(64 \mathrm{~m}^{3}\right)$, with a groundwater (0.8 salinity) exchange of $0.5 \mathrm{~L} / \mathrm{s}$, natural photoperiod, temperature $9-28{ }^{\circ} \mathrm{C}$ and fed with commercial pellets by automatic dispenser. Another sampling (constituting the $27 \%$ of this lot, Table 1) was made 1 year later (July 1997). This second sampling was utilized to check any changes in skeletal anomalies after 1 year spent in unpolluted waters, as a further control of the presence of phenotypic plasticity for at least this species.

The hatchery-reared thick lipped mullet obtained by experimental reproduction carried out in March 1997 at the "La Rosa" hatchery located in the Orbetello lagoon (Grosseto, Italy). Females $(n=11)$ were treated with $10 \mathrm{mg}$ Domperidone (a dopamine
Table 1

Characteristics of samples

\begin{tabular}{llrrrr}
\hline Species & Code & \multicolumn{1}{c}{$n$} & \multicolumn{1}{c}{ SL } & S.D. & Total \\
\hline $0+$ & & & & & \\
C. labrosus & CLg & 118 & 16.85 & 2.73 & 351 \\
& CLle & 186 & 19.99 & 2.09 & \\
& CLr & 47 & 8.43 & 0.89 & \\
L. aurata & LAg & 200 & 23.19 & 2.02 & 347 \\
& LAle & 147 & 23.72 & 3.81 & \\
L. ramada & LRg & 148 & 17.50 & 1.23 & 406 \\
& LRle & 258 & 16.69 & 1.59 & \\
M. cephalus & MCf & 246 & 22.68 & 1.69 & 627 \\
& MCg & 195 & 24.00 & 5.29 & \\
Total & MCle & 186 & 18.71 & 1.74 & \\
1+ & & & & & 1731 \\
C. labrosus & CLg & 0 & - & - & 41 \\
& CLle & 41 & 198.88 & 14.11 & \\
L. aurata & LAg & 108 & 164.94 & 26.59 & 163 \\
& LAle & 55 & 129.29 & 8.58 & \\
L. ramada & LRg & 54 & 153.56 & 11.58 & 70 \\
M. cephalus & LRle & 16 & 150.63 & 60.73 & \\
& MCf & 93 & 86.73 & 9.44 & 164 \\
& MCg & 50 & 322.74 & 19.04 & \\
& MCle & 21 & 194.81 & 77.10 & \\
& & & & & 438
\end{tabular}

Total

$0+$, Indicates fry at the first migration in the brackish water (youngof-the-year); $1+$, sub-adults; $n$, number of individuals; SL, mean standard length in mm; S.D., standard deviation; total, total number of individuals; f, Fiumicino (Tyrrhenian Sea); g, Goro (northern Adriatic Sea); le, Lesina (southern Adriatic Sea); r, reared.

antagonist) $+100 \mu \mathrm{g}$ Luteinizing Hormone-Releasing Hormone (LHRH-a)/kg live fish. Males were not treated. Other details of the rearing protocol are described in Crosetti et al. (1998).

\subsection{Sampling and methodology}

We observed a total of 2169 individuals, $79 \%$ of which were fry and the remainder sub-adults (Table 1), collected in freshwater during the seasonal migration (spring and autumn 1997) by purse-seine. C. labrosus accounted for $18 \%$ of samples, L. aurata $24 \%, L$. ramada $22 \%$ and $M$. cephalus $36 \%$.

All the fry samples $(n=1731)$ were anaesthetized (ethylene glycol-monophenyl ether, Merck, 0.2-0.5 $\mathrm{ml} \mathrm{l}^{-1}$ ), fixed in buffered formalin (10\%) and stained 
in toto with alizarin red for calcified structures and Alcian blue for cartilage (Park and Kim, 1984; Taylor and Van Dyke, 1985).

Sub-adults $(n=438)$ were preserved at $-10{ }^{\circ} \mathrm{C}$, and then X-rayed $(4 \mathrm{~min} / 5 \mathrm{~mA} / 80 \mathrm{~kW})$. Each fish was observed by two operators.

Anatomical terminology was used according to Harder (1975) and Matsuoka (1987).

Meristic counts (on both sides of the body in fry samples, only on the left side for sub-adults) and a survey of skeletal and developmental anomalies were then carried out (the list of anomaly typologies considered is shown in Table 2).

Table 2

List of observed anomalies

\begin{tabular}{|c|c|}
\hline \multicolumn{2}{|l|}{ Region } \\
\hline A & Cephalic vertebrae (carrying epipleural ribs) \\
\hline $\mathrm{B}$ & $\begin{array}{l}\text { Pre-hemal vertebrae (carrying epipleural and pleural } \\
\text { ribs and with open hemal arch, without hemal spine) }\end{array}$ \\
\hline $\mathrm{C}$ & $\begin{array}{l}\text { Hemal vertebrae (with hemal arches closed by } \\
\text { hemal spines) }\end{array}$ \\
\hline $\mathrm{D}$ & $\begin{array}{l}\text { Caudal vertebrae (with hemal and neural arches } \\
\text { closed by modified spines) }\end{array}$ \\
\hline $\mathrm{E}$ & Pectoral fin \\
\hline $\mathrm{F}$ & Anal fin \\
\hline G & Caudal fin \\
\hline $\mathrm{H}$ & First dorsal rays \\
\hline I & Second dorsal rays \\
\hline \multicolumn{2}{|l|}{ Type } \\
\hline 1 & $\underline{\text { Lordosis }}$ \\
\hline 2 & $\underline{\text { Kyphosis }}$ \\
\hline 3 & $\overline{\text { Vertebral fusion }}$ \\
\hline 4 & Malformed vertebral body \\
\hline 5 & Malformed neural arch and/or spine \\
\hline 6 & Malformed hemal arch and/or spine and/or rib \\
\hline 7 & Malformed ray (deformed, absent, fused, supernumerary) \\
\hline 8 & $\begin{array}{l}\text { Malformed pterygophore (deformed, absent, fused, } \\
\text { supernumerary) }\end{array}$ \\
\hline 9 & $\begin{array}{l}\text { Malformed hypural (deformed, absent, fused, } \\
\text { supernumerary) }\end{array}$ \\
\hline 10 & $\begin{array}{l}\text { Malformed epural (deformed, absent, fused, } \\
\text { supernumerary) }\end{array}$ \\
\hline 12 & $\underline{\text { Swim-bladder anomaly }}$ \\
\hline 13 & $\begin{array}{l}\text { Presence of calculi in the terminal tract of the } \\
\text { urinary ducts }\end{array}$ \\
\hline 14 & Malformed pre-maxillary and/or maxillary \\
\hline 15 & Malformed dental \\
\hline 16 & Other splanchno-cranium anomalies \\
\hline 17 & Deformed or reduced left opercle \\
\hline 18 & Malformed predorsal bones \\
\hline
\end{tabular}

Underline indicates anomalies, which are considered as 'severe'.

\subsection{Data analysis}

The numerical data set obtained for skeletal anomalies was processed in order to compute incidences and to perform a descriptive analysis for each descriptor (anomaly typology) and fish sample. The frequency of each anomaly was calculated separately for each species, life stage and origin (total $=18$ samples).

The frequency of the observed anomalies in all samples was then subjected to correspondence analysis (CA, Benzécri et al., 1973) in order to visualize the differences or relationships among samples and the role each anomaly played in defining the characteristics of each sample. A new binary variable (ABS) was added to those expressing skeletal abnormalities: it had unit value (i.e. was true) for specimens with no abnormalities and null value for specimens with at least one abnormality. This variable was needed in order to correctly represent the frequency of specimens without abnormalities in each group, as a null data vector (i.e. a record for a specimen without abnormalities) cannot be processed by any of the techniques that require vector normalisation (e.g. by correspondence analysis).

Indicator species analysis (Dufrêne and Legendre, 1997) was used to define which anomalies were significantly associated with each sample, at the aim at verifying the existence of some species-specific anomaly. Indicator species analysis allows an indicator value (INDVAL) to be defined for each anomaly, in all the fish samples. The INDVALs are then recomputed many times after random permutations of the data matrix, in order to define their empirical distributions for randomly generated groups. If the largest INDVAL for a given anomaly is larger than 95\% (or 99\%) of the INDVALs in the corresponding empirical distribution, then the hypothesis of random occurrence of that anomaly among samples can be rejected and the anomaly can be considered as significantly associated with the sample in which it has the largest INDVAL.

In order to verify if the differences in skeletal anomalies pattern observed among the samples were significant, a multi-response permutation procedure (MRPP) (Berry et al., 1983; Mielke, 1984) was applied. MRPP is a non-parametric procedure for testing the hypothesis of no difference between two or more groups of entities. In particular, MRPP tests whether the observed mean intra-group distance is significantly smaller than the one that is expected in the case of randomly generated 
groups, that is the MRPP verifies the hypothesis of identity among two or more batches as defined a priori, and evaluates their degree of homogeneity.

Pair-wise differences between frequencies of the skeletal anomalies were also tested in young-of-theyear stages (0+) of M. cephalus (StatSoft, Inc., 2001. Statistica Data Analysis Software System, Version 6).

\section{Results}

As far as the meristic counts are concerned, in Tables 3 and 4 the observed values in young-of-theyear and sub-adults are shown, respectively. The range of values was wider in juveniles than in sub-adults, but the median values were constant in all batches. So,

Table 3

Meristic counts in young-of-the year mullets

\begin{tabular}{|c|c|c|c|c|c|c|c|c|c|c|}
\hline & CLg & CLle & CLr & $\mathrm{LAg}$ & LAle & LRg & LRle & $\mathrm{MCf}$ & $\mathrm{MCg}$ & MCle \\
\hline \multicolumn{11}{|l|}{ Vertebrae } \\
\hline Min-max & 24 & $24-25$ & 24 & 23-25 & $23-25$ & $23-25$ & 24 & 23-25 & $24-25$ & 23-25 \\
\hline Median & 24 & 24 & 24 & 24 & 24 & 24 & 24 & 24 & 24 & 24 \\
\hline \multicolumn{11}{|c|}{ Upper caudal dermatotrichia ${ }^{a}$} \\
\hline Min-max & $7-9$ & $7-10$ & $*$ & $7-9$ & $7-9$ & $7-9$ & $6-12$ & $6-9$ & $6-9$ & $6-9$ \\
\hline Median & 8 & 8 & $*$ & 8 & 8 & 8 & 8 & 8 & 8 & 8 \\
\hline \multicolumn{11}{|c|}{ Upper caudal lepidotrichia $^{a}$} \\
\hline Min-max & 8 & 8 & 8 & 8 & 8 & $8-9$ & $8-9$ & 8 & 8 & 8 \\
\hline Median & 8 & 8 & 8 & 8 & 8 & 8 & 8 & 8 & 8 & 8 \\
\hline \multicolumn{11}{|c|}{ Lower caudal lepidotrichia $^{a}$} \\
\hline Min-max & $8-9$ & 8 & 8 & 8 & 8 & 8 & $8-9$ & $7-8$ & $7-8$ & $7-8$ \\
\hline Median & 8 & 8 & 8 & 8 & 8 & 8 & 8 & 8 & 8 & 8 \\
\hline \multicolumn{11}{|c|}{ Lower caudal dermatotrichia ${ }^{a}$} \\
\hline Min-max & $6-10$ & $7-10$ & $*$ & $8-10$ & $7-10$ & $7-9$ & $7-10$ & $7-10$ & $6-12$ & $7-10$ \\
\hline Median & 8 & 8 & $*$ & 9 & 9 & 8 & 8 & 8 & 8 & 8 \\
\hline \multicolumn{11}{|l|}{ Epural $^{\mathrm{a}}$} \\
\hline Min-max & $2-3$ & 2 & $*$ & 2 & 2 & 2 & $2-3$ & $1-2$ & 2 & 2 \\
\hline Median & 2 & 2 & $*$ & 2 & 2 & 2 & 2 & 2 & 2 & 2 \\
\hline \multicolumn{11}{|l|}{ Hypural $^{\mathrm{a}}$} \\
\hline Min-max & $3-4$ & 3 & $*$ & $3-4$ & 3 & $2-3$ & 3 & 3 & 3 & 3 \\
\hline Median & 3 & 3 & $*$ & 3 & 3 & 3 & 3 & 3 & 3 & 3 \\
\hline \multicolumn{11}{|c|}{ Anal lepidotrichia } \\
\hline Min-max & $11-\mathbf{1 3}$ & 11-13 & $11-12$ & $11-\mathbf{1 3}$ & $11-\mathbf{1 3}$ & $11-\mathbf{1 3}$ & $11-\mathbf{1 3}$ & 10-11 & 10-12 & 10-12 \\
\hline Median & 12 & 12 & 12 & 12 & 12 & 12 & 12 & 11 & 11 & 11 \\
\hline \multicolumn{11}{|c|}{ Anterior dorsal lepidotrichia } \\
\hline Min-max & $4-5$ & 4 & $4-5$ & 3-4 & 4 & 4 & $4-6$ & $3-5$ & 4 & 4 \\
\hline Median & 4 & 4 & 4 & 4 & 4 & 4 & 4 & 4 & 4 & 4 \\
\hline \multicolumn{11}{|c|}{ Posterior dorsal lepidotrichia } \\
\hline Min-max & $9-10$ & $9-10$ & $8-10$ & 8-10 & 8-10 & $8-9$ & 8-10 & 9 & $8-10$ & 9-10 \\
\hline Median & 9 & 9 & 9 & 9 & 9 & 9 & 9 & 9 & 9 & 9 \\
\hline \multicolumn{11}{|c|}{ Pectoral lepidotrichia } \\
\hline Min-max & $16-19^{\mathrm{a}}$ & $17-20^{\mathrm{a}}$ & $15-18^{\mathrm{a}}$ & $16-19^{\mathrm{a}}$ & $16-19^{\mathrm{a}}$ & $16-20^{\mathrm{a}}$ & $16-20^{\mathrm{a}}$ & $16-19$ & $16-18$ & $16-19$ \\
\hline Median & 18 & 18 & 17 & 18 & 18 & 18 & 18 & 17 & 17 & 17 \\
\hline \multicolumn{11}{|c|}{ Pectoral pterygiophores ${ }^{\mathrm{a}}$} \\
\hline Min-max & 4 & 4 & 4 & $4-5$ & 4 & $3-4$ & 4 & 4 & 4 & 4 \\
\hline Median & 4 & 4 & 4 & 4 & 4 & 4 & 4 & 4 & 4 & 4 \\
\hline
\end{tabular}

See Table 1 for the codes of the different batchs. Symbol asterisk $\left(^{*}\right)$ denotes not yet differentiated; bold, highlights range values differing from those reported in literature as typical of each species.

${ }^{\text {a }}$ Unvailable datum in literature. 
Table 4

Meristic counts in sub-adult mullets

\begin{tabular}{|c|c|c|c|c|c|c|c|c|}
\hline & CLle & $\mathrm{LAg}$ & LAle & $\mathrm{LRg}$ & LRle & $\mathrm{MCf}$ & $\mathrm{MCg}$ & $\mathrm{MCle}$ \\
\hline \multicolumn{9}{|l|}{ Vertebrae } \\
\hline Min-max & 24 & 24 & 24 & 23-24 & 24 & $23-25$ & 24 & 24 \\
\hline Median & 24 & 24 & 24 & 24 & 24 & 24 & 24 & 24 \\
\hline \multicolumn{9}{|c|}{ Upper caudal dermatotrichia $^{a}$} \\
\hline Min-max & $9-13$ & $*$ & $8-14$ & $*$ & $9-13$ & $*$ & 8 & $*$ \\
\hline Median & 10 & $*$ & 10 & $*$ & 11 & $*$ & 8 & $*$ \\
\hline \multicolumn{9}{|c|}{ Upper caudal lepidotrichia ${ }^{a}$} \\
\hline Min-max & 8 & $7-8$ & 8 & $7-8$ & 8 & 8 & 8 & 8 \\
\hline Median & 8 & 8 & 8 & 8 & 8 & 8 & 8 & 8 \\
\hline \multicolumn{9}{|c|}{ Lower caudal lepidotrichia $^{a}$} \\
\hline Min-max & 8 & 8 & 8 & 8 & 8 & 8 & 8 & 8 \\
\hline Median & 8 & 8 & 8 & 8 & 8 & 8 & 8 & 8 \\
\hline \multicolumn{9}{|c|}{ Lower caudal dermatotrichia $^{a}$} \\
\hline Min-max & $9-13$ & $*$ & $8-13$ & $*$ & $9-13$ & $*$ & 8 & $*$ \\
\hline Median & 11 & $*$ & 10 & $*$ & 11 & $*$ & 8 & $*$ \\
\hline \multicolumn{9}{|l|}{ Epural $^{\mathrm{a}}$} \\
\hline Min-max & 2 & 2 & 2 & $2-3$ & 2 & 2 & 2 & 2 \\
\hline Median & 2 & 2 & 2 & 2 & 2 & 2 & 2 & 2 \\
\hline \multicolumn{9}{|l|}{ Hypural $^{\mathrm{a}}$} \\
\hline Min-max & 3 & 3 & 3 & $2-3$ & 3 & 3 & 3 & 3 \\
\hline Median & 3 & 3 & 3 & 3 & 3 & 3 & 3 & 3 \\
\hline \multicolumn{9}{|c|}{ Anal lepidotrichia } \\
\hline Min-max & 12 & $11-13$ & $12-13$ & $11-12$ & $11-12$ & 11 & 10-11 & 11 \\
\hline Median & 12 & 12 & 12 & 12 & 12 & 11 & 11 & 11 \\
\hline \multicolumn{9}{|c|}{ Anterior dorsal lepidotrichia } \\
\hline Min-max & 4 & 4 & 4 & 4 & 4 & 4 & 4 & 4 \\
\hline Median & 4 & 4 & 4 & 4 & 4 & 4 & 4 & 4 \\
\hline \multicolumn{9}{|c|}{ Posterior dorsal lepidotrichia } \\
\hline Min-max & 9 & $8-10$ & $9-10$ & $8-10$ & $8-9$ & $8-9$ & 8-10 & 8-10 \\
\hline Median & 9 & 9 & 9 & 9 & 9 & 9 & 9 & 9 \\
\hline \multicolumn{9}{|c|}{ Pectoral lepidotrichia } \\
\hline Min-max & $*$ & $*$ & $*$ & $*$ & $*$ & $*$ & $*$ & $*$ \\
\hline Median & $*$ & $*$ & $*$ & $*$ & $*$ & $*$ & $*$ & $*$ \\
\hline \multicolumn{9}{|c|}{ Pectoral pterygiophores $^{\mathrm{a}}$} \\
\hline Min-max & $*$ & $*$ & $*$ & $*$ & $*$ & $*$ & $*$ & $*$ \\
\hline Median & $*$ & $*$ & $*$ & $*$ & $*$ & $*$ & $*$ & $*$ \\
\hline
\end{tabular}

See Table 1 for the codes of the different batches. Symbol asterisk (*) denotes element undetectable in X-ray; bold, highlights range values differing from those reported in literature as typical of each species.

${ }^{\text {a }}$ Unvailable datum in literature.

meristic characters did not show important variations among the lots, differently from skeletal anomalies data (Tables 5-7). As far as skeletal anomalies are concerned, 29 different typologies were observed, some of which are shown in Figs. 2-5, for each species. Anomalies never observed were lordosis, kyphosis and vertebral fusion in cephalic vertebrae (coded as A1, A2 and A3 in Table 2, respectively), malformation of epipleural ribs (A6), kyphosis (B2) and vertebral fusion (B3) in pre-hemal vertebrae, fusion of hemal vertebrae (C3), lordosis and kyphosis in caudal vertebrae (D1 and D2), swim-bladder 
Table 5

Results of skeletal anomalies (meristic count variations not included) assessment of mullet batches

\begin{tabular}{|c|c|c|c|c|c|c|c|c|c|c|c|}
\hline \multicolumn{5}{|l|}{ Origin } & & \multicolumn{6}{|l|}{ Species } \\
\hline Total & Lesina & Goro & Fiumicino & Hatchery & & $\mathrm{CL}_{\text {total }}$ & $\mathrm{CL}_{\text {wild }}$ & LA & LR & $\mathrm{MC}_{\text {total }}$ & $\mathrm{MC}_{\text {adriatic }}$ \\
\hline 2169 & 910 & 873 & 339 & 47 & No. observed individuals & 392 & 345 & 510 & 476 & 791 & 452 \\
\hline 357 & 135 & 139 & 43 & 40 & Malformed individuals $(n)$ & 113 & 73 & 44 & 66 & 134 & 91 \\
\hline 16.5 & 14.8 & 15.9 & 12.7 & 85.1 & Malformed individuals (\%) & 28.8 & 21.2 & 8.6 & 13.9 & 16.9 & 20.1 \\
\hline 721 & 207 & 341 & 86 & 87 & No. of total anomalies ${ }^{\mathrm{a}}$ & 199 & 112 & 80 & 170 & 272 & 186 \\
\hline 2.0 & 1.5 & 2.4 & 2.0 & 2.2 & Average anomalies load ${ }^{\mathrm{b}}$ & 1.8 & 1.5 & 1.8 & 2.6 & 2.0 & 2.0 \\
\hline 1.5 & 1.4 & 0.9 & 0.6 & 21.3 & $\begin{array}{l}\text { Individuals with at least } \\
\text { one severe anomaly }(\%)^{\mathrm{c}}\end{array}$ & 4.1 & 1.7 & 0.8 & 1.5 & 0.8 & 0.9 \\
\hline 83 & 25 & 42 & 4 & 12 & Severe anomalies $(n)^{\mathrm{d}}$ & 27 & 15 & 7 & 37 & 12 & 8 \\
\hline 11.5 & 12.1 & 12.3 & 4.7 & 13.8 & Severe anomalies $(\%)^{\mathrm{e}}$ & 13.6 & 13.4 & 8.8 & 21.8 & 4.4 & 9.2 \\
\hline 2.5 & 1.9 & 5.3 & 4.7 & 1.2 & Severe anomalies load ${ }^{\mathrm{f}}$ & 1.7 & 2.5 & 1.8 & 5.3 & 2.0 & 2.0 \\
\hline
\end{tabular}

Data showed in the left-hand columns are processed according to the batches origin, in the right-hand columns according to the species. $\mathrm{CL}_{\text {total }}$ are relevant to all the $C$. labrosus batches, including reared one, while $\mathrm{CL}_{\text {wild }}$ refers to the Adriatic batches only. $\mathrm{MC}_{\text {total }}$ includes every $M$. cephalus batches, including Fiumicino one; this latter has been excluded, on the contrary, in the column entitled $\mathrm{MC}_{\mathrm{adriatic}}$. Bold highlights the highest observed values for some categories.

${ }^{\text {a }}$ Number of anomalies observed, in each batch.

b Calculated as (number of total anomalies/number of malformed individuals), in each batch

${ }^{c}$ Frequency (\%) of individuals (on the total observed in each batch) with severe anomalies (evidenced in Table 2), in each batch.

${ }^{\mathrm{d}}$ Number of severe anomalies observed in total and in each batch.

e Calculated as (number of severe anomalies/number of total anomalies), in each batch.

${ }^{\mathrm{f}}$ Calculated as (number of severe anomalies/number of individuals with severe anomalies), in each batch.

anomalies (code 12), calculi in terminal tract of the urinary ducts (code 13) and anomalies of splanchnocranium different from deformation of upper and lower jaws, and opercle. All the other anomalies listed in Table 2 have been observed in at least one fish. In Table 5, the results of morphological assessment based only on skeletal anomalies analysis are displayed by origin and by species. The thick lipped mullets from the aquaculture experimental reproduction showed the highest frequency of malformed individuals (85\%) (Table 5). The highest frequency of individuals with at least one skeletal anomaly among the wild samples was observed in the Goro batches, where about $16 \%$ of individuals were malformed, with an average of 2-3 anomalies in each individual (see average anomaly load in Table 5). L. ramada was found to be the most affected by severe anomalies, as evidenced in the right-hand columns of Table 5. In fact, even if wild C. labrosus had a higher frequency of malformed individuals (as many as $21 \%$ of the individuals showed at least one anomaly), L. ramada batches were characterized by a lower frequency of malformed individuals, but each malformed individual had a greater number of anomalies than the other species, as evidenced by the average anomalies load in Table 5.
Furthermore, severe anomalies accounted for about $22 \%$ of total anomalies observed in this species, with an average load of 5.3 anomalies/individual.

In order to identify some skeletal descriptors specific of the sampling sites and/or the species, specimens were grouped in 18 different lots according to the age and origin. The frequency matrix of the anomalies in all batches (matrix $=30$ descriptors $\times 18$ batches) was then subjected to correspondence analysis. The anomaly types that were absent, or extremely rare, in all batches (i.e. anomalies whose number of total observations in all batches $\leq 1$ ) were eliminated from the matrix (total: 29 anomaly types + ABS variable). The ordination in the planes defined by the first two axes (CA1 and CA2, totalling $61 \%$ of the overall variance) is shown in Fig. 6. This ordination is characterized by an evident eccentricity of the reared batch, that is CLr, given the peculiar anomaly pattern displayed. The malformation of predorsal bones (code 18 in Table 2), for instance, is exclusive to this batch. Further, two sub-adult batches, both sampled in Goro, are located in the negative space of CA2, while the other batches are displaced towards the axis origin. For this reason, the ordination in the planes defined by the second and 
Table 6

Results of indicator species analysis: for each anomaly average and maximum values are indicated, according to the species

\begin{tabular}{|c|c|c|c|c|c|c|c|c|}
\hline & 总 & $\sum^{\star}$ & 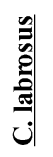 & 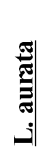 & 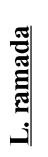 & 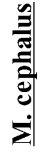 & $\mathbf{P}$ & \\
\hline A4 & 6 & 18 & 7 & 0 & 18 & 0 & 0.757 & \\
\hline A5 & 10 & 32 & 8 & 0 & 32 & 1 & 0.337 & \\
\hline B1 & 6 & 25 & 25 & 0 & 0 & 0 & 0.652 & \\
\hline B4 & 6 & 25 & 0 & 0 & 25 & 0 & 0.691 & \\
\hline B5 & 8 & 14 & 4 & 2 & 12 & 14 & 0.896 & \\
\hline B6 & 12 & 26 & 7 & 14 & 1 & 26 & 0.545 & \\
\hline $\mathrm{C} 1$ & 10 & 27 & 27 & 3 & 8 & 0 & 0.404 & \\
\hline $\mathrm{C} 2$ & 6 & 20 & 20 & 5 & 0 & 0 & 0.776 & \\
\hline $\mathrm{C} 4$ & 12 & 32 & 16 & 1 & 32 & 0 & 0.46 & \\
\hline C5 & 15 & 30 & 12 & 0 & 19 & 30 & 0.707 & \\
\hline C6 & 22 & 44 & 29 & 4 & 9 & 44 & 0.618 & \\
\hline D3 & 11 & 44 & 0 & 44 & 0 & 2 & 0.081 & \\
\hline D4 & 12 & 33 & 33 & 0 & 14 & 2 & 0.429 & \\
\hline D5 & 17 & 32 & 32 & 2 & 23 & 9 & 0.427 & \\
\hline D6 & 13 & 24 & 24 & 5 & 13 & 11 & 0.89 & \\
\hline E7 & 4 & 17 & 0 & 0 & 0 & 17 & 1.0 & \\
\hline E8 & 18 & 65 & 65 & 0 & 6 & 0 & 0.11 & \\
\hline F7 & 17 & 64 & 64 & 0 & 0 & 5 & 0.024 & * \\
\hline F8 & 18 & 46 & 8 & 10 & 46 & 9 & 0.456 & \\
\hline G7 & 6 & 17 & 5 & 17 & 4 & 0 & 0.837 & \\
\hline G9 & 8 & 16 & 16 & 1 & 13 & 1 & 0.89 & \\
\hline G10 & 12 & 46 & 46 & 0 & 0 & 3 & 0.191 & \\
\hline $\mathrm{H} 7$ & 11 & 29 & 29 & 14 & 0 & 2 & 0.37 & \\
\hline H8 & 22 & 31 & 25 & 17 & 31 & 14 & 0.918 & \\
\hline I7 & 12 & 48 & 48 & 0 & 0 & 1 & 0.093 & \\
\hline I8 & 19 & 40 & 17 & 11 & 40 & 8 & 0.716 & \\
\hline 15 & 4 & 17 & 0 & 0 & 0 & 17 & 0.999 & \\
\hline 17 & 6 & 16 & 0 & 16 & 9 & 0 & 0.764 & \\
\hline 18 & 6 & 25 & 25 & 0 & 0 & 0 & 0.666 & \\
\hline abs & 25 & 29 & 19 & 29 & 26 & 26 & 0.012 & * \\
\hline
\end{tabular}

ABS, binary variable having a unit value for specimens with no abnormalities and a null value for specimens with at least one abnormality. $* p<0.05$.

third factorial axes (CA2 and CA3, accounting for $39 \%$ of the overall variance) are also taken into account and the ordination is shown separately for each batch (Fig. 7). Observation of the species ordination shows that the CA2 axes discriminate between young-of-the-year (indicated with $0+$ in Figs. 6 and 7) and sub-adult (1+) lots, with the sole exception of L. aurata. Further, as far as C. labrosus is concerned, the $0+$ batch cluster is opposite to the $1+$ batch, while in the case of L. ramada and M. cephalus, the CA3 separates the Goro 1+ batches from all the others. The anomalies ordination, which contributes to such structure, is shown in Fig. 8. Some anomalies
Table 7

Results of indicator species analysis: for each anomaly average and maximum values are indicated, according to the Adriatic sampling sites

\begin{tabular}{|c|c|c|c|c|c|}
\hline & 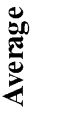 & $\underset{\Sigma}{\Sigma}$ & હુ & & $\mathbf{p}$ \\
\hline A4 & 13 & 25 & 0 & 25 & 0.463 \\
\hline A5 & 12 & 23 & $I$ & 23 & 0.727 \\
\hline B1 & 6 & 13 & 0 & 13 & 0.999 \\
\hline B4 & 7 & 14 & 14 & 0 & 0.459 \\
\hline B5 & 14 & 27 & 27 & 1 & 0.309 \\
\hline B6 & 24 & 42 & 7 & 42 & 0.294 \\
\hline C1 & 14 & 24 & 5 & 24 & 0.474 \\
\hline $\mathrm{C} 2$ & 13 & 25 & 0 & 25 & 0.451 \\
\hline $\mathrm{C} 4$ & 19 & 30 & 30 & 8 & 0.456 \\
\hline $\mathrm{C} 5$ & 41 & 79 & 79 & 2 & $0.017 *$ \\
\hline C6 & 48 & 82 & 82 & 13 & 0.088 \\
\hline D3 & 19 & 38 & 0 & 38 & 0.209 \\
\hline D4 & 20 & 37 & 37 & 4 & 0.357 \\
\hline D5 & 27 & 38 & 38 & 17 & 0.476 \\
\hline D6 & 26 & 40 & 40 & 11 & 0.4 \\
\hline E7 & 6 & 13 & 0 & 13 & 0.999 \\
\hline E8 & 18 & 25 & 25 & 11 & 0.636 \\
\hline F7 & 14 & 24 & 24 & 4 & 0.503 \\
\hline F8 & 47 & 83 & 83 & 10 & $0.036 *$ \\
\hline G7 & 21 & 43 & 43 & 0 & 0.082 \\
\hline G9 & 17 & 31 & 31 & 3 & 0.388 \\
\hline G10 & 18 & 34 & 34 & 3 & 0.215 \\
\hline H7 & 13 & 15 & 11 & 15 & 0.999 \\
\hline H8 & 46 & 67 & 67 & 25 & 0.257 \\
\hline I7 & 14 & 29 & 29 & 0 & 0.198 \\
\hline I8 & 44 & 67 & 67 & 20 & 0.278 \\
\hline a17 & 13 & 25 & 0 & 25 & 0.47 \\
\hline abs & 50 & 51 & 49 & 51. & 0.41 \\
\hline
\end{tabular}

ABS, binary variable having a unit value for specimens with no abnormalities and a null value for specimens with at least one abnormality. ${ }^{*} p<0.05$.

appear to be strongly specific to some batches, i.e. C5 and C6 were found to be associated with M. cephalus, and $\mathrm{C} 4$ and B4 with L. ramada sub-adults, both sampled at Goro. All the anomalies located in the negative CA2 plane are representative of the $0+$ and Lesina $1+$ batches.

The specificity of the skeletal anomalies for different species and Adriatic sampling sites (Goro versus Lesina) was checked using indicator species analysis (INDVAL), the results of which are shown in Tables 6 and 7, respectively. In this procedure Fiumicino batches were not considered owing to the paucity of malformed individuals found (only 43), 

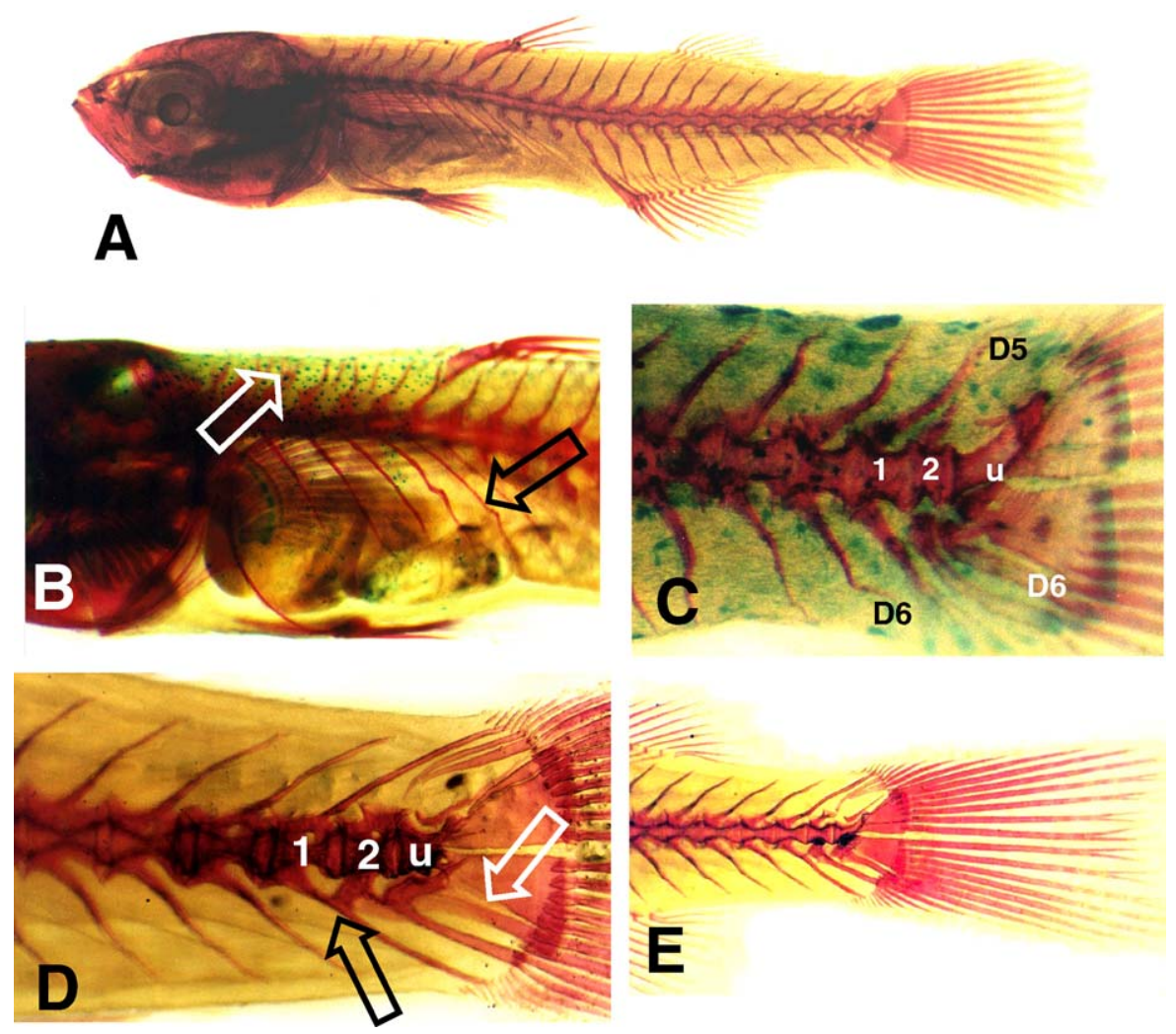

Fig. 2. Examples of some skeletal anomalies in C. labrosus. (A) Young-of-the year without anomalies. (B) The white arrow points to neural spines of cranial and pre-hemal vertebrae, which did not close to form a normal closed neural arch. The black arrow points to abnormal pleural ribs. (C) Severely deformed reared post-larva (28 days-post-hatching). Caudal vertebrae (1 and 2) and urostyle are fused one each other, and both neural (D5) and hemal spines (black D6) are deformed. Further, the hemal arch of the second caudal vertebra and paraipuroapophysys are detached from corrispective vertebral body (white D6). (D) The hemal arch of the first caudal vertebrae is fused with the second caudal vertebra one (black arrow). One hemal arch is between the second caudal vertebra and urostyle (u) arch, carrying two hemal spines (white arrow). (E) Normal caudal region.

which does not reach a minimum number of observation for this statistics (for this reason, we tested the differences in skeletal anomalies frequencies among all the M. cephalus samples with the two-sided test, further on reported). As far as the species are concerned, INDVAL results (Table 6) indicated that only two of the indicator values of the 30 descriptors reached the significant threshold $(p<0.05)$ : F7 (deformed anal ray), which was found to be significantly associated with C. labrosus, and the absence of anomalies (ABS), which displayed maximum specificity for $L$. aurata. Also INDVAL application to the Adriatic sampling sites (Table 7) gave a significant indicator value for only two anomalies, namely C5 and F8, with maximum specificity for the Goro batches.
The two-sided test was applied to all the $M$. cephalus samples (Fiumicino included) and the only significant differences among frequencies of the skeletal anomalies in $M$. cephalus young-of-the-year stages were those related to pre-hemal and hemal vertebrae with malformed arch and/or spine and/or rib (B6 and C6) ( $p=0.05$, two-sided test).

As one of the goals of this study was to verify the possibility that differences exist among the skeletal anomaly patterns shown by fish sampled in different sites, the differences among skeletal anomalies were tested in batches of different sampling sites by performing a MRPP; the null hypothesis was no differences in the skeletal anomalies among the Fiumicino, Goro and Lesina batches. The results show (Table 8) that the null hypothesis (H0) of 

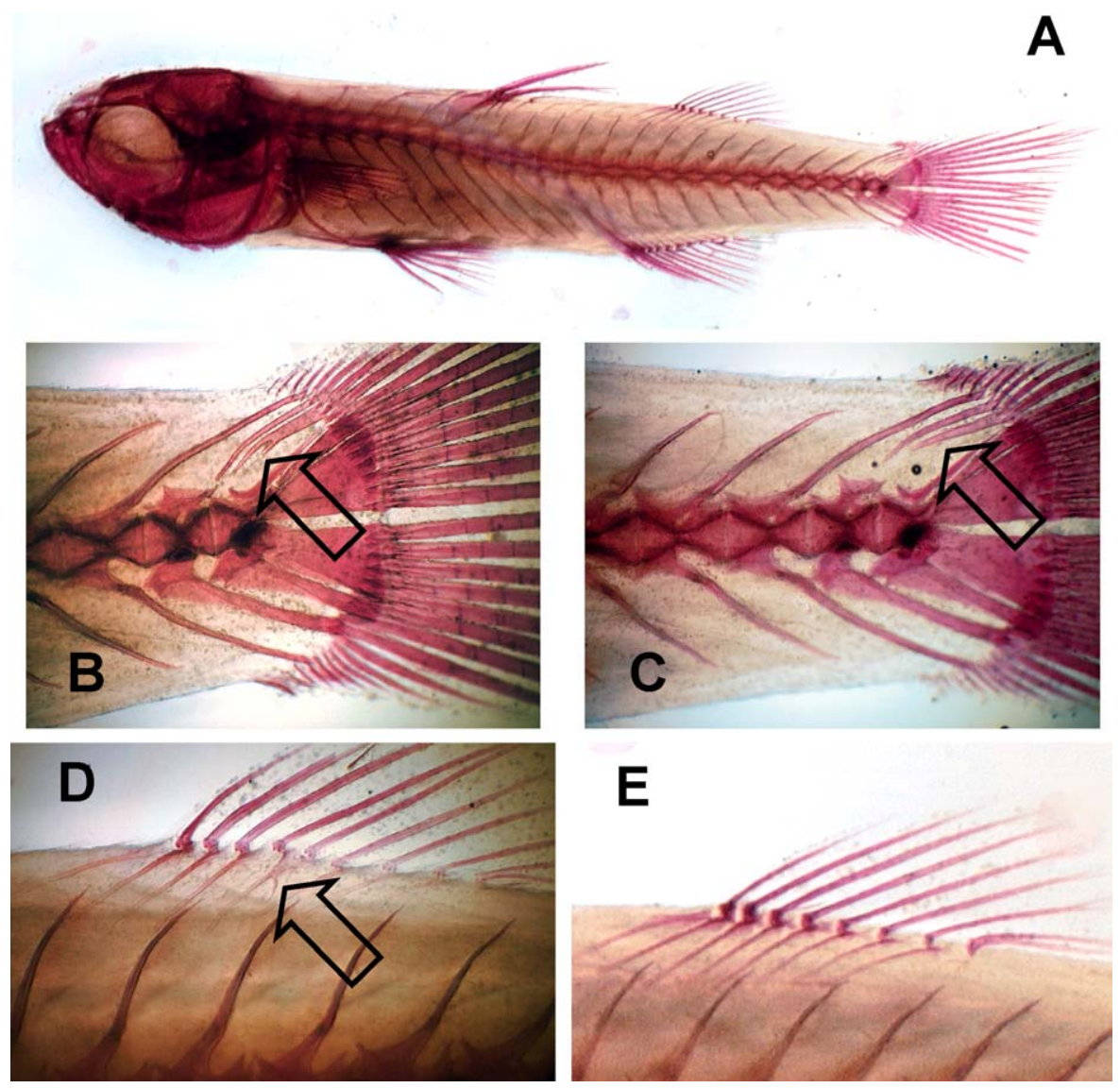

Fig. 3. Examples of some skeletal anomaly in L. aurata. (A) Young-of-the year without anomalies. (B) The arrow points to abnormal epural (compare with $\mathrm{C}$ for the normal morphology). (D) Bifurcated pterygiophore of the posterior dorsal fin. (E) Normal posterior dorsal fin.

Table 8

MRPP results: in the upper rows the values inherent the within-batch homogeneity are reported, while in the lower rows those relatives to the null hypothesis of between-batches identity

\begin{tabular}{|c|c|c|c|c|c|c|}
\hline & \multicolumn{2}{|c|}{$0+(\mathrm{GO} / \mathrm{LE} / \mathrm{FI})$} & \multicolumn{2}{|c|}{$1+(\mathrm{GO} / \mathrm{LE} / \mathrm{FI})$} & \multicolumn{2}{|l|}{ Species } \\
\hline & Batch & Average (d) & Batch & Average (d) & Batch & Average (d) \\
\hline & GO & 0.432828 & GO & $1.323423^{\mathrm{a}}$ & C. labrosus & $0.634943^{\mathrm{a}}$ \\
\hline & LE & 0.454123 & LE & 0.581648 & L. aurata & 0.330769 \\
\hline & FI & $0.614022^{\mathrm{a}}$ & FI & 0.203856 & L. ramada & $0.568349^{\mathrm{a}}$ \\
\hline & & & & & M. cephalus & $0.641341^{\mathrm{a}}$ \\
\hline Test $T$ statistic & & -3.16745 & & -8.72849 & & -19.2487 \\
\hline Observed delta & & 0.469144 & & 0.860465 & & 0.549241 \\
\hline Expected delta & & 0.469947 & & 0.8735 & & 0.554332 \\
\hline$P(\mathrm{~T})$ & & $1.39 \mathrm{E}-02$ & & $1.62 \mathrm{E}-05$ & & $5.21 \mathrm{E}-12$ \\
\hline$p$-Level & & $<0.01$ & & $<0.01$ & & $<0.01$ \\
\hline
\end{tabular}

Null hypothesis $(\mathrm{H} 0)$

Rejected H0

Rejected H0

The null hypothesis (H0) of equal observed and expected deltas (i.e. mean intra-group distances) was rejected for sub-adults batches. 0+, youngof-the-year; 1+, sub-adults; FI, Fiumicino; GO, Goro; LE, Lesina.

${ }^{a}$ Highest homogeneity values. 

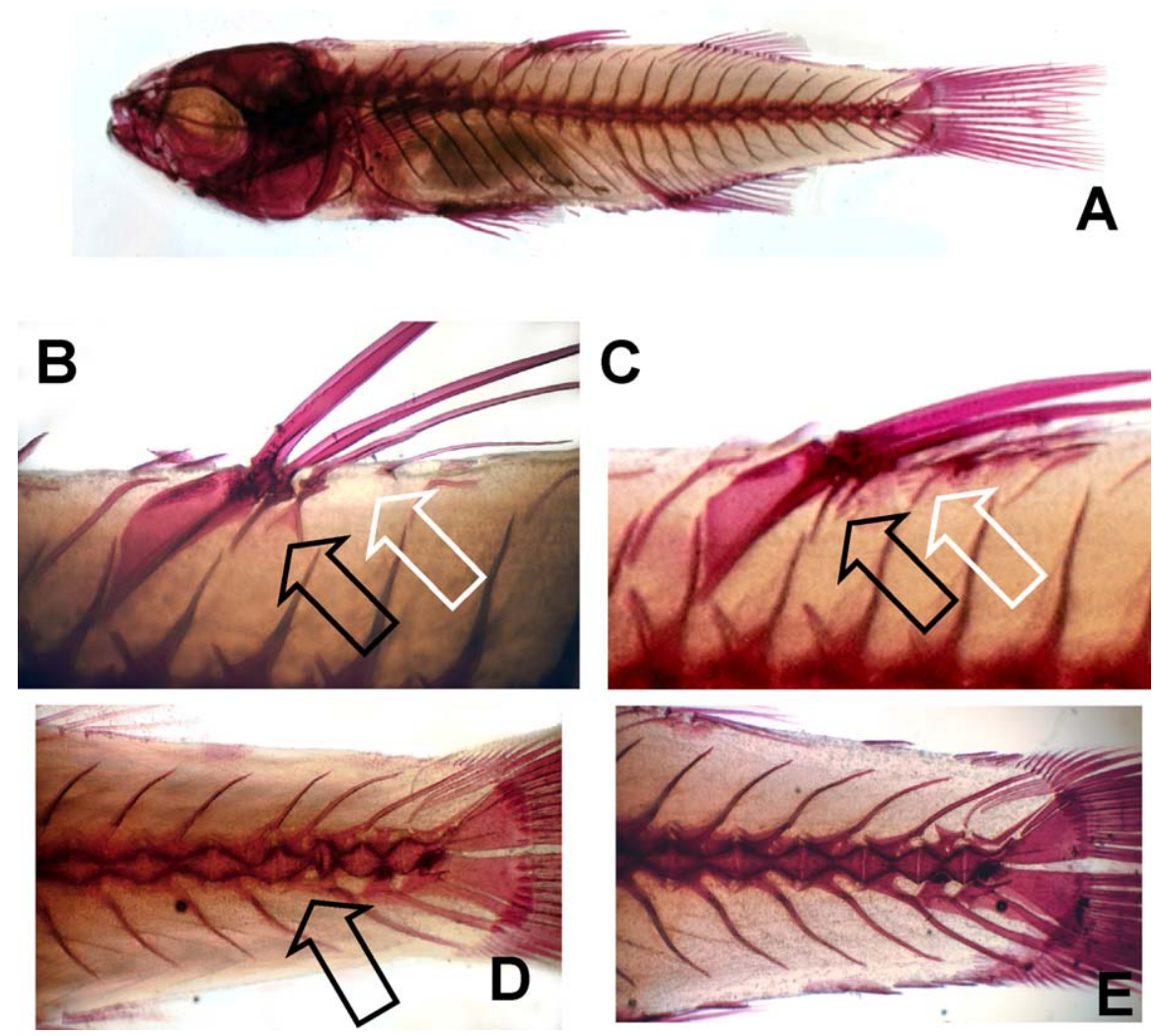

Fig. 4. Examples of some skeletal anomalies in L. ramada. (A) Young-of-the-year without anomalies. (B) The black arrow points at a fusion occurring between the pterygiophores of the third and fourth rays of the first dorsal fin. The fourth ray is not supported by any pterygiophore (white arrow). (C) Normal pterygiophores arrangement of the first dorsal fin. (D) The arrow points at a fusion occurring between the last hemal vertebra and the first caudal vertebrae. Both the vertebral bodies resulted to be deformed and the first caudal vertebra lacks its hemal arch. Compare with $\mathrm{E}$ for the normal condition.

absence of differences between the two sampling sites was rejected only when sub-adult individuals $(1+)$ of the different sites were considered. This means that the sub-adult skeletal anomaly pattern differed significantly among the batches from the three sampling sites. In particular, the $1+$ Goro batch was the one characterized by the greatest internal homogeneity. A similar comparison was performed among the different species, considering only wild individuals (to the exclusion of reared batches) (right-hand column in Table 8). The null hypothesis was again rejected, allowing the existence of a within-species homogeneity higher than expected under the null hypothesis of a non-specific anomaly pattern to be inferred for all the species but not for L. aurata.

\section{Discussion}

This study represents the first survey on meristic counts and skeletal anomalies in four mullet species sampled in a natural environment and can be used as a preliminary basis for further biomonitoring studies.

As a result of our investigations of meristic counts, we found that the median values of each character did not differ among the fish sampled in the different sites, and only variations in minimum and maximum values appeared within the batches.

The skeletal anomaly frequencies evidenced a maximum in reared C. labrosus ( $85.1 \%$ ), a sign of how distant the controlled reproduction and farming conditions are from the optimal ones. The observed frequencies of malformed wild individuals were 

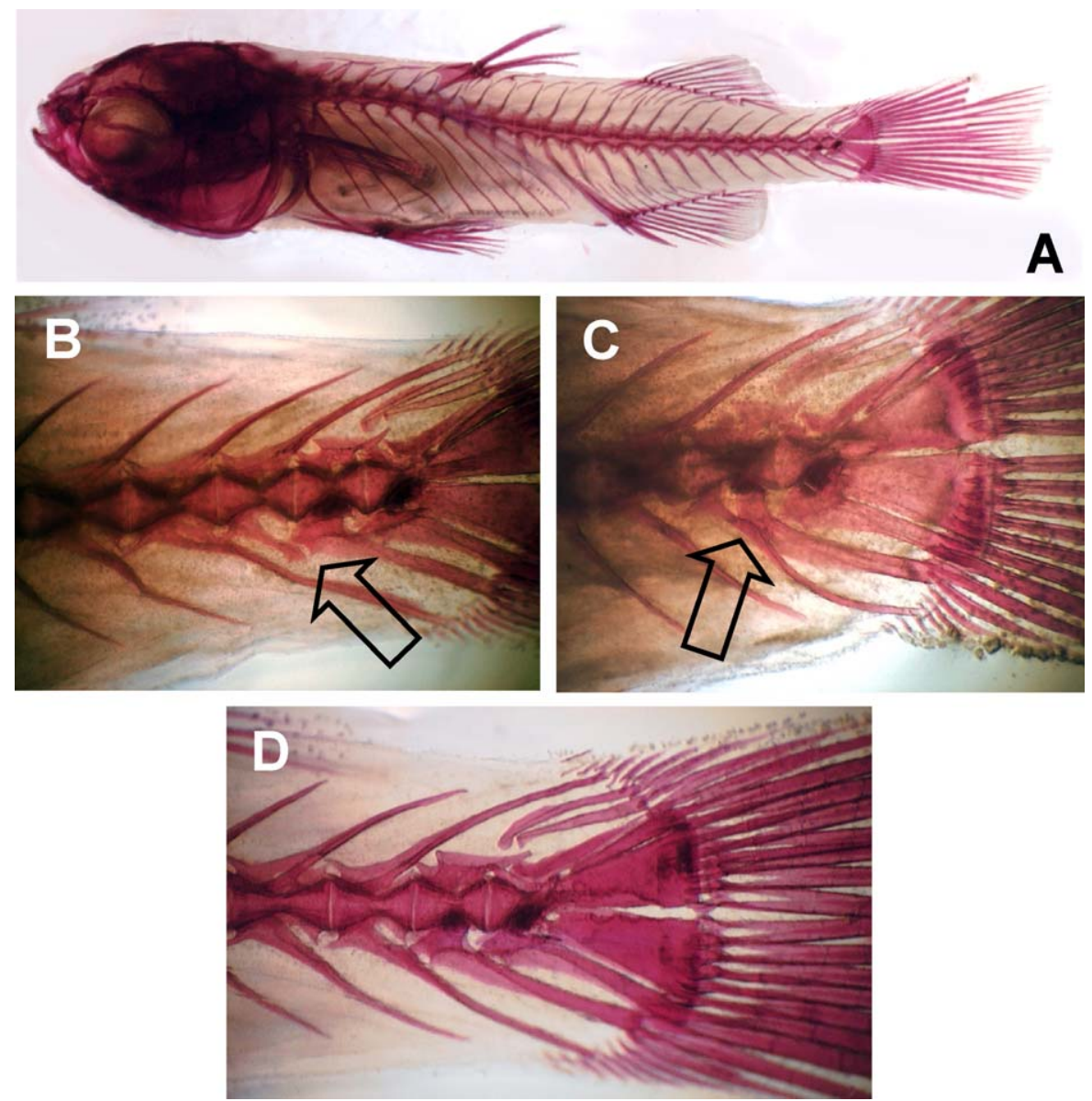

Fig. 5. Examples of some skeletal anomalies in M. cephalus. (A) Young-of-the-year without anomalies. (B) The arrows points at a hemal arch lacking the hemal spine. (C) One caudal vertebra carries two hemal arches (arrow). (D) Normal caudal region.

higher than those reported in literature for unpolluted areas, ranging from $8.6 \%$ in L. aurata to $21.2 \%$ in $C$. labrosus. In Karr's Index of Biotic Integrity (Karr et al., 1986) environmental conditions are considered good when less than $2 \%$ of fish are affected by fin damage and skeletal anomalies. Between 2 and 5\% is reported for somewhat degraded ecosystems and over $5 \%$ for highly degraded systems. In an unpolluted estuary, only $0.06 \%$ of deformed fish were found (Dahlberg, 1970): it should be stressed that in a healthy fish population not affected by pollution, a number of crippled or sick individuals will normally exist, which should be considered as background noise (Svanberg and Bengtsson, 1996). A method we considered suitable to isolate the normal phenotypic plasticity from environmentally induced phenodeviants was to observe the frequencies of $M$. cephalus deformed individuals in the 1-year-stocked batch in unpolluted water (sub-adult MCf batch). We found only 6 of the 93 MCf sub-adults $(6 \%)$ had light malformations and none showed severe anomalies, which were observed only in two Fiumicino young-ofthe-year. The absence of severely deformed individuals in the lot MGf sub-adults prevent us from inputting their data in INDVAL analysis, but this signifies by itself a substantial confirm of the validity of such reference lot. So, if we subtract $6 \%$ of normal phenodeviants from the percentage of $\mathrm{MC}_{\text {adriatic }}$ misshapen individuals, we obtain $14 \%$ of phenodeviants presumably induced by the local environmental 


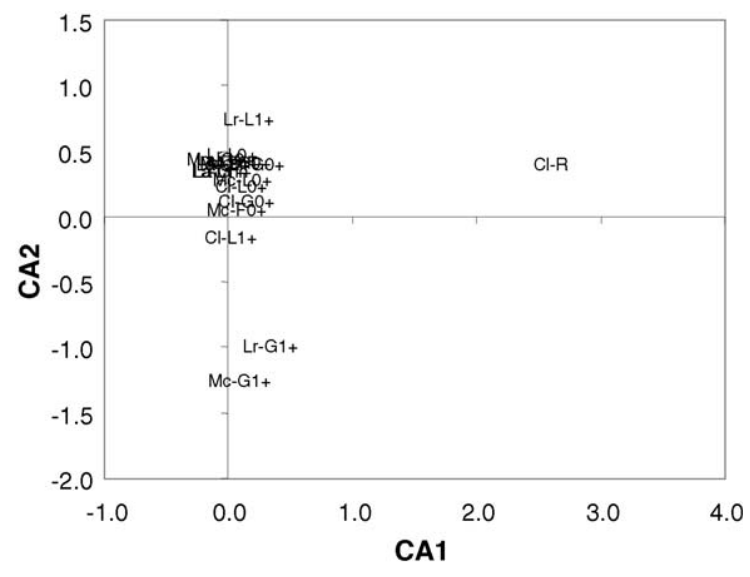

Fig. 6. Correspondence analysis: ordination of samples in the first two factorial axes (CA1 and CA2) plane. These axes account for $61 \%$ of total variance. $\mathrm{Cl}$, C. labrosus; $\mathrm{La}, L$. aurata; $\mathrm{Lr}$, L. ramada; Mc, M. cephalus; 0+, young-of-the-year; 1+, sub-adult; F, Fiumicino; G, Goro; L, Lesina; R, reared.

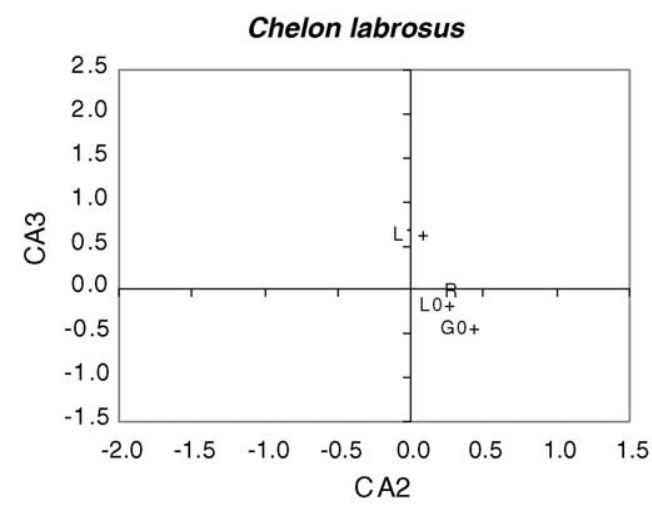

Liza ramada

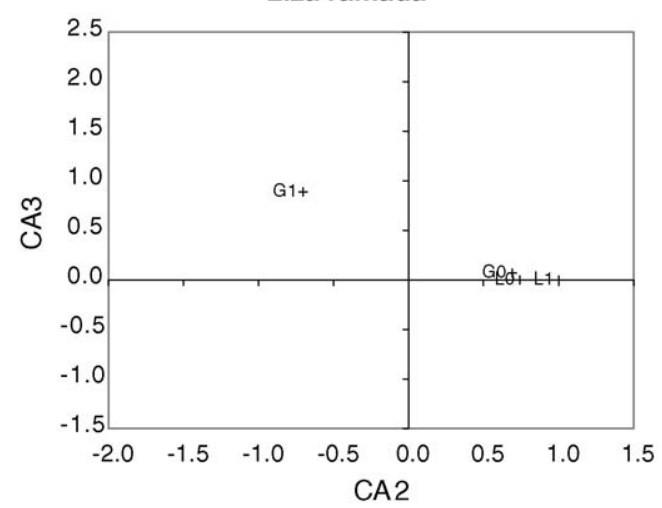

conditions. If we observe the percentages of severely deformed individuals in Adriatic populations we find lower than expected values for somewhat degraded ecosystems, but we detect multiple severe deformities in many individuals. While wild C. labrosus exhibited a higher frequency of deformed individuals $(21.2 \%)$ than $L$. ramada, each deformed individual had an average of 1.5 anomalies, while $L$ ramada had 2.6 (Table 5). Also, only $1.5 \%$ of the observed L. ramada were found to be severely affected by anomalies (versus $1.7 \%$ of wild C. labrosus) but each of the severely deformed $L$. ramada displayed an average of 5.3 severe deformations (compared with 2.5 in $C$. labrosus). The decision making of classifying nonserious and serious deformities is difficult (Kingsford and Gray, 1996; Kingsford et al., 1996), but it could be justified by the attempt to have sound estimates of frequency of anomalies in populations of wild fish.
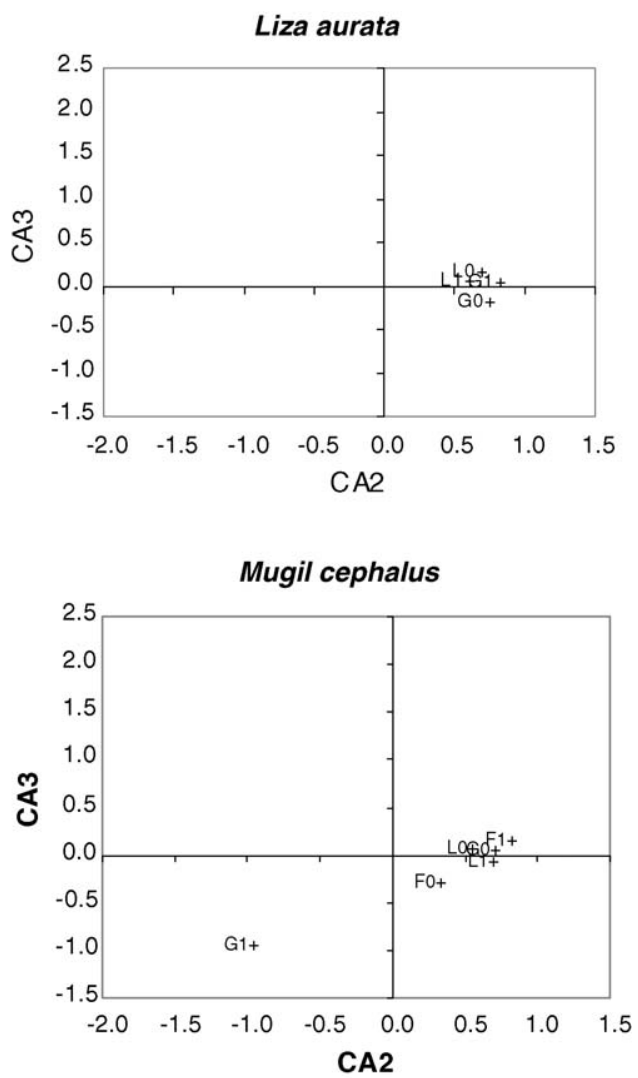

Fig. 7. Correspondence analysis: ordination of different lots according to the species in the second and third factorial axis (CA2 and CA3) plane. These axes account for 39\% of total variance. 0+, Young-of-the-year; 1+, sub-adult; F, Fiumicino; G, Goro; L, Lesina; R, reared. 


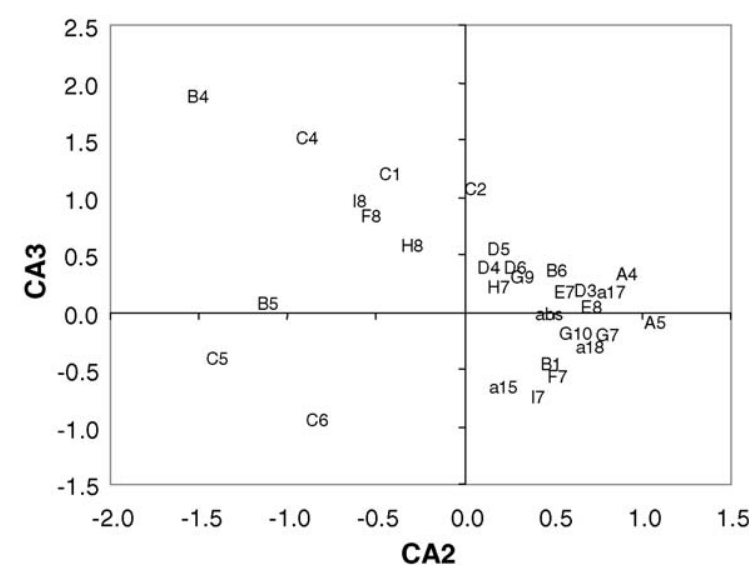

Fig. 8. Correspondence analysis: ordination of mullet skeletal anomalies in the second and third factorial axis (CA2 and CA3) plane. This ordination can be considered as an additional layer in the previous one, as objects (samples) and variables (anomalies) can be represented in the same ordination by $\mathrm{CA}$.

Further, small total percentages of seriously deformed fish should not be taken as meaning that this is insignificant or interpreted as a justification for classifying waters as "healthy" environments (Kingsford et al., 1996).

The higher load of severe anomalies displayed by L. ramada could be linked to the peculiarity of this species to feed on the finest sediment particles (mud) from the sediment: $63-125 \mu \mathrm{m}$ particles constitute the $52.4 \%$ (up to $100 \%$, in fish sampled in areas where this fraction is the predominant inorganic part of the sediment) of the inorganic part in intestinal contents, unlike the other mullet in which $125-250 \mu \mathrm{m}$ particles are mainly selected (Mariani et al., 1987). The finest particle sizes go to make up the mud component of the sediment: estuarine sediments are often the most heavily polluted marine environments owing to communal and industrial effluent discharge as well as pesticide input from agricultural runoff and antifouling agents. They may act not only as sinks but also as secondary sources of persistent pollutants (Hartl, 2002).

We must not be deceived by the quite comparable frequencies of deformed individuals found both in Sacca di Goro (15.9\%) and the Lesina lagoon (14.8\%): while Lesina mullet displayed only rare multiple deformations (as indicated by an average anomaly load of 1.5), Goro individuals showed an average of
2.4 anomalies/individual. As far as the frequencies of severely deformed individuals are concerned, $1.4 \%$ of Lesina fishes were found to be severely deformed, compared with $0.9 \%$ at Goro, but with an average severe anomaly load of 5.3 versus the 1.9 observed in the Lesina batches. The INDVAL applied to the sampling sites gave significance to these differences, evidencing specificity for some anomalies for Goro and not for the Lesina batches, and the MRPP stressed a greater internal homogeneity in Goro than in the Lesina batches. Consequently, as the Goro batches appear to be more strongly 'characterized' than the Lesina ones, it may be postulated that the Sacca di Goro environment is more stressful for fish than the Lesina one. In particular, the industrial contamination (heavy metals, i.e.), whose presence was found close to the Po River delta and in Goro lagoon (Coquery et al., 1996; Tankéré and Statham, 1996; Marchini et al., 2004), could be considered as the causative factor. Consequently, as in Lesina sources of pollution are mainly agriculture, surface runoff, urban population discharges, we can deem skeletal anomalies to be less induced by such agricultural and civil contaminants.

Thus, this study seems to confirm the use of mullet as sentinel species in biomonitoring studies, that is, species whose morphological/life history characteristics provide a good indication of the condition of all the fish in the receiving environment (Courtenay et al., 1998). There are reports in the literature of wild L. aurata, M. cephalus and $C$. labrosus giving positive results in investigations of fluoride levels in bone and muscle in individuals sampled near to and remote from point sources (Milhaud et al., 1981). M. cephalus has already been used in experimental exposure to pollutants (crude oil, Sindermann, 1996), developing fin erosion within 6-8 days from exposure. In the present study, the fact that skeletal patterns displayed were found to be site-specific (see MRPP and two-sided test results) for all species but $L$. aurata, indicates that three of the mullet species are sensitive to environmental conditions. Further, the fact that the skeletal pattern proved also species-specificity in three of the four tested species (C. labrosus, L. ramada and $M$. cephalus), and that the two (on the 30 considered) descriptors which attained the significance threshold in INDVAL (deformed anal ray, F7 associated with 
C. labrosus, and the absence of anomalies, specific to L. aurata) were not the same that resulted statistically different when the two-sided test was applied to only $M$. cephalus data, means that it is not possible to use single skeletal anomalies as indicators of stressful environmental conditions for at least two (C. labrosus, $L$. ramada) of the considered fish species. Further surveys should be undertaken to verify the use of C6 and B6 anomalies as indicators in M. cephalus.

$L$. aurata was the species characterized by the lowest frequency of deformed individuals $(8.6 \%$ and only $0.8 \%$ of total observed fish was found to be severely deformed) and by a non-specific skeletal pattern. It may therefore be postulated that this species is less sensitive to environmental conditions than the other tested mullet. It is quite difficult to explain why this species showed a lower frequency of anomalies (which could be interpreted as a higher developmental homeostasis) than the other mullet. The young-of-the-year of this species was found to be strongly affected by competition with other mullet fry, because it never occurred alone in Mediterranean estuarine areas and had a very narrow niche. Further, it recruits in winter, when zooplankton is very scarce. Consequently, more than $80 \%$ of the stomach contents of L. aurata fry caught in the Canal Vell lagoon (Spain) consisted of adult Chironomus salinarius, unlike the other mullet fry that fed mainly on detritus, cyclopoids, calanoids and cladocerans (Gisbert et al., 1995). In the Sacca of Scardovari (Po River delta), L. aurata (standard length $>30 \mathrm{~mm}$ ) higher relative quantities of polychaetes, amphipods and adult insects were found in the stomach than in L. ramada. In bigger individuals, differences between the two species diet were greater: both fed mainly on adult insects, but in $L$. aurata $(51 \mathrm{~mm})$ amphipods, vegetal detritus and sand were those more likely to be chosen, while $L$. ramada fed mostly on calanoids and mysids (Chieregato et al., 1981). So, while the other mullets fed mainly on filtering organisms, L. aurata seems to be obliged by mullet fry competition to eat organic detritus and adult insects, and thus bio-accumulates fewer toxic substances. Another possible explanation for the low malformation load observed in L. aurata batches could be a loss of genetic variability in this species through the elimination of sensitive indivi- duals and alleles due to the increased selective pressure resulting from contamination stress (Lavie and Nevo, 1982, 1988; Diamond et al., 1989): several laboratory and field studies have shown that an acquired resistance to polluted environments can be obtained at the expense of a diminution in genetic variability (Chagnon and Guttman, 1989; Klerks and Levinton, 1989; Cognetti, 1991; Heagler et al., 1993; Keklak et al., 1994). Furthermore, the genetic adaptation of a fish population under chronic stress and the development of genetic resistance in fish used as environmental sentinels was found to have the capacity to reduce the sensitivity and efficacy of monitoring programs (Kirchhoff et al., 1999). Differences in responsiveness had already been found among fish belonging to the same family, the types of deformities observed in each Gobiidae species in the same environment proved to be strongly related to the genus of each species ( $\mathrm{Da}$ Cunha and Antunes, 1999), and some species were found to be more sensitive than others to the adverse effects of pollutants (as demonstrated in salmonids in relation to halogenated diaromatic hydrocarbons by Walker and Peterson, 1994). Furthermore, it was demonstrated that in the same species, various populations can develop differing responses towards environmental stressors, and their genetic tolerance could mask the actual effects of pollutants (Gyllensten and Ryman, 1985; Prince and Cooper, 1995a,b). Further studies are needed to account for these differences among species reacting to the same environment.

Another interesting aspect that emerges from this study is that the skeletal patterns in sub-adult batches (all but $L$. aurata) were found to be significantly associated with the sampling sites (Table 7), but not those of young-of-the-year batches, in which many skeletal anomalies should be considered as "background noise" (Svanberg, 1996). We observed also a greater variability in meristic counts in younger individuals than in sub-adult ones. The reduced meristic variability and the greater within-group homogeneity in skeletal anomalies of the sub-adult batches could be due to the smaller number of examined sub-adults than $0+$ individuals, thus making further closer inspections necessary in order to confirm this. On the other hand, even if fish larvae are considered to be particularly vulnerable to 
pollutants, Kingsford et al. (1996) found that the manifestation of the larval deformities they described was independent of the pollution regimes experienced by the larvae, as natural deformities occur in the early developmental forms of fish ("background noise" of Svanberg). The causes could be temperature, genetic abnormalities, difficulties at hatching and quality of maternal yolk. Genetic differences between the inland migrating Liza populations and those returning to the sea were demonstrated by Papa et al. (2003). Whether or not both genetic and morphological differences can be traced back to natural selection or genetic drift must be further investigated. Other surveys, based on larger numbers of fry and sub-adults of the same species, are necessary before the hypothesis of a higher descriptive capacity is assigned to sub-adults than to young-ofthe-year in the evaluation of skeletal anomalies occurring in wild mullet.

In conclusion, the variation in skeletal anomalies observed between the two Adriatic sites indicates that they may be under the influence of environmental contaminants or factors which stress the Sacca di Goro batches more than the Lesina ones, and that $C$. labrosus, $L$. ramada and $L$. aurata may be used in biomonitoring surveys of sites whose pollution degree is unknown.

\section{Acknowledgements}

We would like to thank Dr. Donatella Crosetti (ICRAM) for her valued collaboration, and two anonymous referees for their constructive criticism, which considerably ameliorated this paper.

\section{References}

Alford, R.A., Bradfield, K.S., Richards, S.J., 1997. Measuring and analysing developmental instability as a tool for monitoring frog populations. In: Campbell, A. (Ed.), Declines and Disappearances of Australian Frogs. Environment Australia, Canberra, pp. 34-43.

Bengtsson, B.E., 1979. Biological variables, especially skeletal deformities in fish, for monitoring marine pollution. Philos. Trans. R. Soc. Lond. B 286, 457-464.

Bengtsson, B.E., 1988. Effects of pulp mill effluents on skeletal parameters in fish-a progress report. Water Sci. Technol. 20, 87-94.
Bengtsson, B.E., Bengtsson, A., Himberg, M., 1985. Fish deformities and pollution in some Swedish waters. Ambio 14, 32-35.

Bengtsson, B.E., Bengtsson, A., Tjärnlund, U., 1988. Effects of pulp mill effluents on vertebrae of fourhorn sculpin, Myoxocephalus quadricornis, bleak, Alburnus alburnus, and perch, Perca fluviatilis. Arch. Environ. Contam. Toxicol. 17, 789-797.

Benzécri, J.P., et al., 1973. L'Analyse des Données, vol. 2. Dunod, Paris, France.

Berry, K.J., Kvamme, K.L., Mielke Jr., P.W., 1983. Improvements in the permutation test for the spatial analysis of the distribution of artifacts into classes. Am. Antiquity 48, 547-553.

Bondavalli, C., 2003. Effect of eutrophication upon radionuclide dynamics in the Sacca di Goro lagoon (Po River Delta, Italy): a combined field, experimental and modeling study. Environ. Pollut. 125, 433-446.

Capanna, E., Cataudella, S., Monaco, G., 1974. The pharyngeal structure of Mediterranean mugilidae. Monitore Zool. Ital. 5 (8), 29-46.

Carls, M.G., Rice, S.D., 1990. Abnormal development and growth reductions of pollock, Theragra chalcogramma, embryos exposed to water-soluble fractions of oil. Fish. Bull. 88, 29-37.

Chagnon, N.L., Guttman, S.I., 1989. Differential survivorship of allozyme genotype in mosquito fish populations exposed to copper and cadmium. Environ. Toxicol. Chem. 23, 705728.

Chieregato, A.R., Ferrari, I., Rossi, R., 1981. Ricerca preliminare sul regime alimentare di avannotti di orata, branzino e muggini nella sacca di Scardovari (delta del Po). Quad. Lab. Tecnol. Pesca 3 (Suppl. 1), 249-263.

Christian, R.R., Forés, E., Comin, F., Viaroli, P., Naldi, M., Ferrari, I., 1996. Nitrogen cycling networks of coastal ecosystems: influence of trophic status and primary producer form. Ecol. Model. 87, 111-129.

Clarke, G.M., 1995. The genetic basis of the developmental stability. II. Asymmetry of extreme phenotypes revisited. Am. Nat. 146 (5), 708-725.

Cognetti, G., 1991. Adaptations in marine unpredictable environments. In: Bonotto, S., Nobili, R., Revoltella, R.P. (Eds.), Serono Symposia: Biological Indicators for Environmental Monitoring, 27. pp. 153-160.

Coquery, M., Cossa, D., Gobeil, C., Azemard, S., Sanjuan, J., Magand, O., Horvart, M., 1996. The significance of mercury and methylmercury profiles in coastal sediments. Book of Abstracts, IV, International Conference on Mercury as a Global Pollutant, 4-8 August, Hamburg, Germany, p. 501.

Courtenay, S.C., Parker, W.R., Rawn, G.P., 1998. Proceedings of a Workshop to Assess Alternatives to the Fish Survey Component of the Environmental Effects Monitoring Program for Canadian Pulp and Paper Mills. Fisheries and Oceans, Can. Tech. Rep. Fish. Aquat. Sci. 2233, p. 108.

Crosetti, D., Cataudella, S., 1995. Grey mullet culture. In: Nash, C.E. (Ed.), World Animal Science. 34B: Production of Aquatic Animals" Elsevier, pp. 271-288.

Crosetti, D., Cabiati, A., Cordisco, C., De Innocentiis, S., Finoia, M.G., Gornung, E., Pucci, P., Rossi, A.R., Sola, L., Venturini, G., 
1998. Ecological and productive role of mugilids in aquaculture. Biol. Mar. Medit. 5, 1166-1168.

Da Cunha, P.L., Antunes, M.M., 1999. Occurrence of vertebral deformities in Gobiidae (Pisces) from the Tagus estuary. Aquat. Ecol. 33, 281-285.

Dahlberg, D.M., 1970. Frequencies of abnormalities in Georgia estuarine fishes. Trans. Am. Fish. Soc. 99 (1), 95-97.

Daoulas, C., Economou, A.N., Bantavas, I., 1991. Osteological abnormalities in laboratory reared sea bass (Dicentrarchus labrax) fingerlings. Aquaculture 97, 169-180.

Delaune, R.D., Patrik, W.H., Buresh, R.J., 1978. Sedimentation rates determined by Cs-137 dating in a rapidly accreting salt marsh. Nature 275, 532-533.

Diamond, S.A., Newman, M.C., Mulvey, P., Dixon, P.M., Martinson, D., 1989. Allozyme genotype and time to death of mosquitofish, Gambusia affinis (Baird and Girard), during acute exposure to inorganic mercury. Environ. Toxicol. Chem. 8, 613-622.

Divanach, P., Boglione, C., Menu, B., Koumoundouros, G., Kentouri, M., Cataudella, S., 1996. Abnormalities in finfish mariculture: an overview of the problem, causes and solutions. Handbook of Contributions and Short Communications, International Workshop on Sea Bass and Sea Bream Culture: Problems and Prospects, October 16-18, European Aquaculture Society (EAS), Verona, Italy, pp. 45-66.

Dufrêne, M., Legendre, P., 1997. Species assemblages and indicator species: the need for a flexible asymmetrical approach. Ecol. Monogr. 67 (3), 345-366.

ENVIBASE-Project, 1988. Environmental monitoring: environmental support systems for political decision-making, sustainable environmental planning and reporting. September 1996 until March 1998. Berlin Senate for Urban Development, Environmental Protection and Technology, Department III. Available from http://www.stadtentwicklung.berlin.de/archiv_sensut/ umwelt/uisonline/envibase/envibook.ht.

Ewald, G., 1999. Ecotoxicological aspects of chlorinated fatty acids. Aquat. Ecosyst. Health Manag. 2 (1), 71-80.

Fabbri, D., Gabbianelli, G., Locatelli, C., Lubrano, D., Trombini, C., Vassura, I., 2001. Distribution of mercury and other heavy metals in core sediments of the Northern Adriatic Sea. Water Air Soil Pollut. 129, 143-153.

Fausch, K.D., Lyons, J., Karr, J.R., Angermeier, P.L., 1990. Fish communities as indicators of environmental degradation. Biological Indicators of Stress in Fish. American Fisheries Society Symposium 8, Bethesda, MD, pp. 123-144.

Ferrara, R., Maserti, B.E., 1992. Mercury concentration in the water, particulate matter, plankton and sediment of the Adriatic Sea. Mar. Chem. 38 (3-4), 237-249.

Giordani, G., Azzoni, R., Bartoli, M., Vairoli, P., 1997. Seasonal variations of sulphate reduction rates, sulphur pools and iron availability in the sediment of a dystrophic lagoon (Sacca di Goro, Italy). Water Air Soil Pollut. 99, 363-371.

Gisbert, E., Cardona, L., Castello, F., 1995. Competition between mullet fry. J. Fish Biol. 47, 414-420.

Gyllensten, U., Ryman, N., 1985. Pollution biomonitoring programs and the genetic structure of indicator species. Ambio 14, 29-31.
Haga, Y., Suzuki, T., Kagchika, H., Takeuchi, T., 2003. A retinoic acid receptor-selective agonist causes jaw deformity in the Japanese flounder Paralichthys olivaceus. Aquaculture 221, 381-392.

Harder, W., 1975. Anatomy of Fishes. Part I: Text. E. Schweizerbart'sche Verlagsbuchhandlung (Nägele u. Obermiller), Stuttgart, $612 \mathrm{pp}$.

Hardig, J., Andersson, T., Bengtsson, B.-E., Forlin, L., Larsson, Å., 1988. Long-term effects of bleached kraft mill effluents on red and white blood cell status, ion balance and vertebral structure in fish. Ecotoxicol. Environ. Saf. 15, 96-106.

Hartl, M.G.J., 2002. in: Bright, M., Dworschak, P.C., Stachowitsch, M. (Eds.), Benthic Fish as Sentinel Organisms of Estuarine Sediment Toxicity. The Vienna School of Marine Biology: A Tribute to Jörg Ott. Facultas Universitätsverlag, Wien, pp. 89100.

Haya, K., 1989. Toxicity of pyrethroid insecticides to fish. Environ. Toxicol. Chem. 8, 381-391.

Heagler, M.G., Newman, M.C., Mulvey, M., Dixon, P.M., 1993. Allozyme genotype in mosquito fish, Gambusia holbrooki, during mercury exposure: temporal stability, concentration effects and field verification. Environ. Toxicol. Chem. 12, 385-395.

Karen, D., Klaine, S.J., Ross, P.E., 2001. Further considerations of the skeletal system as a biomarker of episodic chlorpyrifos exposure. Aquat. Toxicol. 52, 285-296.

Karr, J.R., 1981. Assessment of biotic integrity using fish communities. Fisheries 6 (6), 21-27.

Karr, J.R., Fausch, K.D., Angermeier, P.L., Yant, P.R., Schlosser, I.J., 1986. Assessing Biological Integrity in Running Waters. A Method and its Rationale, Illinois Natural History Survey, Special Publication 5, 28 pp.

Keklak, M.M., Newman, M.C., Mulvey, M., 1994. Enhanced uranium tolerance of an exposed population of the eastern mosquitofish (Gambusia holbrooki Girard 1859). Arch. Environ. Toxicol. 27, 20-24.

Kingsford, M.J., Gray, C.A., 1996. Influence of pollutants and oceanography on abundance and deformities of wild fish larvae. In: Schmitt, R.J., Osenberg, C.W. (Eds.), Detecting Ecological Impacts: Concepts and Application in Coastal Habitats. Academic Press, Santa Barbara, pp. 233-253.

Kingsford, M.J., Suthers, I.M., Gray, C.A., 1996. Exposure to sewage plumes and the incidence of deformities in larval fishes. Mar. Pollut. Bull. 33 (7-12), 201-212.

Kirchhoff, S., Sévigny, J.-M., Couillard, C.M., 1999. Genetic and meristic variations in the mummichog Fundulus heteroclitus, living in polluted and reference estuaries. Mar. Environ. Res. 47, 261-283.

Klerks, P.L., Levinton, J.S., 1989. Rapid evolution of metal resistance in a benthic Oligochaete inhabiting a metal polluted site. Biol. Bull. 176, 135-141.

Klumpp, D.W., Humphrey, C., Huasheng, H., Tao, F., 2002. Toxic contaminants and their biological effects in coastal waters of Xiamen China. II. Biomarkers and embryo malformation rates as indicators of pollution stress in fish. Mar. Pollut. Bull. 44 (8), 761-769. 
Latif, M.A., Bodaly, R.A., Johnston, T.A., Fudge, R.J.P., 2001 Effects of environmental and maternally derived methyl mercury on the embryonic and larval stages of walleye (Stizostedion vitreum). Environ. Pollut. 111, 139-148.

Lavie, B., Nevo, E., 1982. Heavy metal selection of phosphoglucose isomerase allozymes in marine gastropods. Mar. Biol. 71, $17-22$.

Lavie, B., Nevo, E., 1988. Multilocus genetic resistance and susceptibility to mercury and cadmium pollution in the marine gastropod, Cerithium scabridum. Aquat. Toxicol. 13, 291-296.

Lemly, A.D., 1997. Ecosystem recovery following selenium contamination in a freshwater reservoir. Ecotoxicol. Environ. Saf. $36,275-281$.

Lemly, A.D., 2002. Symptoms and implications of selenium toxicity in fish: the Belews Lake case example. Aquat. Toxicol. 57, 39-49.

Lindsejöö, E., Thulin, J., 1992. A skeletal deformity of northern pike (Exos lucius) related to pulp mill effluents. Can. J. Fish. Aquat. Sci. 18, 81-93.

Marchini, A., Gauzer, K., Occhipinti-Ambrogi, A., 2004. Spatial and temporal variability of hard-bottom macrofauna in a disturbed coastal lagoon (Sacca di Goro, Po River Delta northwestern Adriatic Sea). Mar. Pollut. Bull. 48, 1084-1095.

Mariani, A., Panella, S., Monaco, G., Cataudella, S., 1987. Size analysis of inorganic particles in the alimentary tracts of Mediterranean mullet species suitable for aquaculture. Aquaculture 62, 123-129.

Matsuoka, M., 1987. Development of skeletal tissue and skeletal muscle in the Red sea bream, Pagrus major. Jpn. J. Ichthyol. 65 (65), 1-114.

Matteucci, G., Frascari, F., 1997. Fluxes of suspended materials in the north Adriatic Sea (Po prodelta area). Water Air Soil Pollut. 99, 557-572.

Mayer Jr., F.L., Bengtsson, B.-E., Hamilton, S.J., Bengtsson, A., 1988. Effects of pulp mill and ore smelter effluents on vertebrae of fourhorn sculpin: laboratory and field comparisons. In: Adams, W.J., Chapman, G.A., Landis, W.G. (Eds.), Aquatic Toxicology and Hazard Assessment, vol. 10. American Society for Testing and Materials, Philadelphia, pp. 406-419 (ASTM STP 971. ERL, GB X569).

Mielke Jr., P.W., 1984. Meteorological applications of permutation techniques based on distance functions. In: Krishnaiah, P.R., Sen, P.K. (Eds.), Handbook of Statistics, vol. 4. Elsevier Science Publishers, pp. 813-830.

Milhaud, G., Bahri, L., Dridi, A., 1981. The effects of fluoride on fish in Gabes Gulf. Fluoride 14, 161-168.

Minissi, S., Lombi, E., 1997. Heavy metal content and mutagenic activity, evaluated by Vicia faba micronucleus test, of Tiber river sediments. Mutat.Res. 393, 17-21.

O'Connor, J., Huggett, R., 1988. Aquatic pollution problems, North Atlantic Coast, including Chesapeake Bay. Aquat. Toxicol. 11, 163-190.

Oberdoff, T., Hughes, R.M., 1992. Modification of an index of biotic integrity based on fish assemblages to characterize rivers of the Seine basin, France. Hydrobiologia 228, 117-130.

Orio, A.A., 1984. Mercury in sediments of the Northern Adriatic Sea. In: FAO/UNEP/WHO/IOC/IAEA Meeting on the Biogeochemical Cycle of Mercury in the Mediterranean, 7-31 August,
Siena, Italy. FAO Fisheries Report No. 325 Supplement, FAO, Rome, pp. 125-127.

Papa, R., Nonnis Marzano, F., Rossi, V., Gandolfi, G., 2003. Genetic diversity and adaptability of two species of Mugilidae (Teleostei: Perciformes) of the Po river delta coastal lagoons. Oceanol. Acta 26, 121-128.

Park, E.H., Kim, D.S., 1984. A procedure for staining cartilage and bone of whole vertebrate larvae while rendering all other tissues transparent. Stain Technol. 59 (5), 269-272.

Pastva, S., Villalobos, S.A., Kannan, K., Giesy, J.P., 2001. Morphological effects of Bisphenol-A on the early life stages of medaka (Orizias latipes). Chemosphere 45, 535-541.

Prince, R., Cooper, K., 1995a. Comparisons of the effects of 2,3,7,8tetrachlorodibenzo- $p$-dioxin on chemically impacted and nonimpacted subpopulations of Fundulus heteroclitus. I. TCCD toxicity. Environ. Toxicol. Chem. 14, 579-589.

Prince, R., Cooper, K., 1995b. Comparisons of the effects of 2,3,7,8tetrachlorodibenzo- $p$-dioxin on chemically impacted and nonimpacted subpopulations of Fundulus heteroclitus. II Metabolic considerations. Environ. Toxicol. Chem. 14, 589-595.

Raicich, F., 1994. A Note on the Flow Rates of the Adriatic rivers. IST-CNR Tech. Rep. RF 2/94, 6 pp.

Robbins, J.A., Edgington, D.N., 1975. Determination of recent sedimentation rates in lake Michigan using Pb-210 and Cs137. Geochim. Cosmochim. Acta 39, 285-304.

Savvaitova, K.A., Chebotareva, Y.V., Pichugin, M.Y., Maksimov, S.V., 1995. Anomalies of fishes as environmental indicators. J. Ichthyol. 35 (2), 182-188.

Sindermann, C.J., 1996. Ocean Pollution. Effects on Living Resources and Humans. Marine Science Series, vol. 7 CRC Press, Boca Raton, New York, London, Tokyo, 304 p.

Sloof, W., 1982. Skeletal anomalies in fish from polluted surface waters. Aquat. Toxicol. 2, 157-173.

Svanberg, O., 1996. Monitoring of biological effects. Resour. Conserv. Recycl. 16, 351-360.

Svanberg, O., Bengtsson, B.E., 1996. Impact of bleached pulp mill effluents on the aquatic environment (The Swedish Environment/Cellulose Project)—a case study. Resour. Conserv. Recycl. 16, 189-199.

Tankéré, S.P.C., Statham, P.J., 1996. Distribution of dissolved Cd, $\mathrm{Cu}, \mathrm{Ni}$ and $\mathrm{Zn}$ in the Adriatic Sea. Mar. Pollut. Bull. 32 (8/9), 623-630.

Tankéré, S.P.C., Price, N.B., Statham, P.J., 2000. Mass balance of trace metals in the Adriatic Sea. J. Mar. Syst. 25, 269286.

Taylor, R., Van Dyke, C., 1985. Revised procedures for staining and clearing small fishes and other vertebrates for bone and cartilage study. Cybium 9 (2), 107-119.

Von Westernhagen, H., Dethlefsen, V., 1997. The use of malformations in pelagic fish embryos for pollution assessment. Hydrobiol 352 (1-3), 241-250.

Walker, M.K., Peterson, R.E., 1994. Aquatic toxicity of dioxins and related chemicals. In: Schecter, A. (Ed.), Dioxins and Health. Plenum Press, New York, pp. 347-387.

Weigand, M.D., Hataley, J.M., Kitchen, C., Buchanan, L., 1989. Induction of developmental abnormalities in larval goldfish (Carassius auratus). J. Fish Biol. 35, 85-95. 
Weis, J.S., Weis, P., 1989. Tolerance and stress in a polluted environment. Bioscience 39 (2), 89-95.

Westeinhagen, H., Dethlefsen, V., Cameron, P., Berg, J., Fürstenberg, G., 1988. Developmental defects in pelagic fish embryos from the western Baltic. Helgolander Meeresunteres 42, 1336.

Whittle, D.M., Sergeant, D.B., Huestis, S.Y., Hyatt, W.H., 1992. Foodchain accumulation of PCDD and PCDF isomers in the Great Lakes aquatic community, 11, in: Damstra, T., Birnbaum,
L., Charles, M.J., Corton, C., Greenlee, W., Lucier, G. (Eds.), International Symposium on Dioxins and Related Compounds. Part 1, vol. 25, no. 1-2, pp. 181-184.

Wilson, P.J., Tillitt, D.E., 1996. Rainbow trout embryotoxicity of a complex contaminant misture extracted from lake Michigan Lake trout. Mar. Environ. Res. 42 (1-4), 129-134.

Yashuov, A., Berner-Samsonov, E., 1970. Contribution to the knowledge of eggs and early larval stages of mullets (Mugilidae) along the Israeli coast. Badmigeh 22 (3), 72-89. 